\title{
Din Görevlilerine Göre Çocuk/Sevgi Evleri’nde Kalan Çocukların Din Eğitimi: Sivas İli Örneği
}

\author{
Rukiye Gögen \\ Arş. Gör. Dr., Sivas Cumhuriyet Üniversitesi (ROR ID: 04f81fm77) \\ İlahiyat Fakültesi, Din Eğitimi Anabilim Dalı \\ Res. Asst. Ph.D., Sivas Cumhuriyet University, Faculty of Theology \\ Department of Religious Education \\ Sivas/Turkey \\ rukiye-yilmaz58@hotmail.com \\ ORCID: 0000-0002-0725-4578
}

\section{Religious Education of Children Staying in Child/Love Houses According to Religious Officials: The Case of Sivas Province}

\begin{abstract}
Child/Love Houses are institutions where children who are separated from their families for various reasons are sheltered under the supervision of the state and their education needs are met. The quality of the religious education given in these institutions, the methods of delivery and the solution of the problems encountered in the education process are of great importance in terms of preparing these children in need of protection for the future. Because it is only possible with education not to make these children who are deprived of family education feel the absence of family as much as possible and to prepare them for the future in a healthy way and to reintegrate them into society. In addition to general education, religious education has an important role in the process of preparing these children for the future in an equipped way. Because religious education is extremely important for the individual to know himself, to have knowledge about beliefs and values, to make sense of life, to have the necessary maturity to adapt to moral development and society. The need for religious education of these children makes the quality of the religious education given to them and the competence of the religious officials giving this education even more important. The purpose of this research is to examine the opinions of religious officials on the religious education of children
\end{abstract}

$\mathrm{Bu}$ çalışma 09.04.2021 tarihinde sunduğumuz “Çocuk İstismarını Önlemede Din Eğitiminin Rolü” başlıklı doktora tezinden üretilerek hazırlanmıştır. Makalenin alan çalışmasıyla ilgili etik kurul izni alınmıştır (Sivas Cumhuriyet Üniversitesi Hukuk Müşavirliği'nin 60263016-050.0604-E.437797 sayılı kararı). / This study has been prepared on the basis of the doctoral dissertation titled "The Role of Religious Education in Preventing Child Abuse" that submitted on 09.04.2021. Ethics committee approval was obtained from Sivas Cumhuriyet University Legal Counseling Office with the decision numbered 60263016-050.0604-E.437797 regarding the field study of the article (Doctoral dissertation, Cumhuriyet University, Sivas, Turkey, 2021).

İtihal Taraması/Plagiarism Detection: Bu makale intihal taramasından geçirildi/This paper was checked for plagiarism Etik Beyan/Ethical Statement: Bu çalısmanın hazırlanma sürecinde bilimsel ve etik ilkelere uyulduğu ve yararlanılan tüm çalışmaların kaynakçada belirtildiği beyan olunur/It is declared that scientific and ethical principles have been followed while carrying out and writing this study and that all the sources used have been properly cited (Rukiye Gögen).

Geliş/Received: 20 Haziran/June 2021 | Kabul/Accepted: 05 Eylül/September 2021| Yayın/Published: 20 Eylül/September 2021

Atıf/Cite as: Rukiye Gögen, "Din Görevlilerine Göre Çocuk/Sevgi Evleri'nde Kalan Çocukların Din Eğitimi: Sivas İli Örneği = Religious Education of Children Staying in Child/Love Houses Accord-ing to Religious Officials: The Case of Sivas Province", Eskiyeni 45 (Eylül/September 2021), 843-873. https://doi.org/10.37697/eskiyeni.955023

CC BY-NC 4.0 This paper is licensed under a Creative Commons Attribution-NonCommercial License 
who have been separated from their families for various reasons and need protection and have to live in Child/Love Homes, and to make some evaluations to increase the quality of religious education given in Child/Love Homes by making use of these opinions. Within the scope of the research, the data of the research were obtained by the semi-structured interview technique from the religious officials working in Sivas Children's and Love Houses. The sample of the research consists of 18 religious officials working in Sivas Children's / Love Houses. These religious officials provide education and guidance services to a total of 108 children living in 17 Children's Houses, 5 Love Houses and 1 Children's Houses Complex. Religious officials whose identity information is kept confidential in the research; Face-to-face questions were asked about their competence in the education given in these institutions, the difficulties and contributions of religious education given to children, and their suggestions for a better religious education. As a result of the research, it has been determined that the religious officials who give religious education to the children living in these houses are professionally experienced but do not have enough equipment in child education. Another important result reached within the scope of the research is that the religious education given in Children's/Love Houses has a positive effect on children, changing their false beliefs and thoughts on religious issues, enabling them to look to the future with hope, and creating awareness of living in accordance with religion in worship and moral issues. As can be understood from these determinations, it is of great importance that the administrators, specialists, educators, housewives and other officials working in Child/Love Homes are carefully selected and the efforts to increase the quality of education provided in these homes are continued.

\section{Keywords}

Religious Education, Child in Need of Protection, Child Houses, Affection Houses, Religious Officials, Sivas

\section{Din Görevlilerine Göre Çocuk/Sevgi Evleri'nde Kalan Çocukların Din Eğitimi: Sivas İli Örneği}

\section{Öz}

Çocuk/Sevgi Evleri, çeşitli nedenlerle ailesinde ayrı kalan çocukların devletin gözetiminde barındığı ve eğitim öğretim ihtiyacının karşılandığı kurumlardır. Bu kurumlarda verilen din eğitiminin niteliği, veriliş yöntemleri ve eğitim sürecinde karşılaşılan sorunların çözümü, korunma ihtiyacı olan bu çocukların geleceğe hazırlanması açısından büyük önem taşımaktadır. Çünkü aile eğitiminden yoksun kalan bu çocuklara mümkün olduğu ölçüde ailenin yokluğunu hissettirmemek ve onları sağlıklı bir şekilde geleceğe hazırlayıp topluma kazandırmak ancak eğitimle mümkündür. Söz konusu çocukların geleceğe donanımlı bir şekilde hazırlanması sürecinde genel eğitim yanında din eğitiminin de önemli bir rolü vardır. Çünkü din eğitimi, bireyin kendini tanıması, inanç ve değerler konusunda bilgi sahibi olması, hayatı anlamlandırması, ahlaki gelişim ve topluma uyum sağlama konusunda gerekli olgunluğa sahip olması açısından son derece önemlidir. Bu çocukların din eğitimine olan ihtiyacı, onlara verilen din eğitiminin niteliğini ve bu eğitimi veren din görevlilerinin yeterliliğini daha da önemli hale getirmektedir. İşte bu araştırmanın amacı, çeşitli nedenlerle ailelerinden ayrı kalarak korunmaya muhtaç hale gelen ve Çocuk/Sevgi Evleri'nde yaşamak durumunda kalan çocukların din eğitimi konusunda din görevlilerinin görüşlerini incelemek ve bu görüşlerden yararlanarak Çocuk/Sevgi Evlerinde verilen din eğitiminin kalitesini artırmaya yönelik bazı değerlendirmelerde bulunmaktır. Araştırma kapsamında Sivas Çocuk ve Sevgi Evleri'nde çalışan din görevlilerinden yarı yapılandıılmış görüşme (mülakat) tekniği ile araştırmanın verileri elde edilmiş- 
tir. Araştırmanın örneklemini, Sivas Çocuk/Sevgi Evleri'nde çalışan 18 din görevlisi oluşturmaktadır. Bu din görevlileri, 17 Çocuk Evi, 5 Sevgi Evi ve 1 de Çocuk Evleri Sitesi'nde kalan toplam 108 çocuğa eğitim ve rehberlik hizmeti sunmaktadır. Araştırmada kimlik bilgileri gizli tutulan din görevlilerine; bu kurumlarda verilen eğitim konusunda yeterliliklerine, çocuklara verilen din eğitiminin zorluklarına, katkılarına, daha iyi bir din eğitimi verilebilmesi için önerilerine dair yüz yüze sorular sorulmuştur. Araştırma sonucunda, bu evlerde kalan çocuklara din eğitimi veren din görevlilerinin mesleki açıdan tecrübeli olduğu ancak çocuk eğitimi konusunda yeterli donanıma sahip olmadığı tespitine ulaşılmıştır. Araştırma kapsamında ulaşılan bir diğer önemli sonuç ise Çocuk/Sevgi Evleri'nde verilen din eğitiminin çocuklar üzerinde olumlu etki bırakarak onların dini konulardaki yanlış inanç ve düşüncelerini değiştirdiği, geleceğe umutla bakmalarını sağladığı, ibadet ve ahlaki konularda dine uygun yaşama bilinci oluşturduğudur. Bu tespitlerden anlaşılacağı gibi, Çocuk/Sevgi Evlerinde görev yapan idarecilerin, uzmanların, eğitimcilerin, ev annelerinin ve diğer görevlilerin özenle seçilmesi ve bu evlerde verilen eğitimin niteliğini artırmaya yönelik çalışmaların süreklilik arz etmesi büyük önem taşımaktadır.

\section{Anahtar Kelimeler}

Din Eğitimi, Korunma İhtiyacı Olan Çocuk, Çocuk Evleri, Sevgi Evleri, Din Görevlileri, Sivas

\section{Giriş}

Bilindiği gibi ülkemizde çeşitli nedenlerle ailesinden ayrı yaşamak durumunda kalan çocuklar devlet tarafından korunma altına alınarak onların temel ihtiyaçları giderilmekte ve sağlıklı, iyi yetişmiş bireyler olarak topluma kazandırılmaları hedeflenmektedir. Bu amaçla ailesi yanında kalması mümkün olmayan çocuklara Aile, Çalışma ve Sosyal Politikalar Bakanlığı bünyesinde kalacak yer imkânı sağlanmaktadır. ${ }^{1}$ Böylece kimsesiz kalan çocuklara Çocuk/Sevgi Evleri adı altında bir aile yuvası oluşturmak ve bu çocuklara aile sıcaklığını hissettirmeye çalışarak bir anlamda ailenin yerine getirmesi gereken sorumlulukları çalışanları görevliler maharetiyle yerine getirmektir.

Aile, Çalışma ve Sosyal Hizmetler Bakanlığı tarafından korunma ihtiyacı olan çocuklara kalacak yer imkânının sağlandığı kurumların başında Sevgi ve Çocuk Evleri gelmektedir. Sevgi Evleri korunma ihtiyacı olan çocukların barınma ve bakımını sağlayan 0-18 yaş grubundaki çocukların kaldığı evlerdir. Çocuk evleri ise her ilin kültürel ve sosyal açıdan çocuk yetiştirmeye müsait bölgelerinde özellikle il merkezlerinde olmak üzere okul ve hastanelere yakın apartman dairesi ya da müstakil evlerde en az beş en çok sekiz çocuğun kaldığı kuruluşlardır. ${ }^{2}$ 0-18 yaş arasındaki korunmaya muhtaç çocukların kaldığı bu evler 2005 yılında 4 ev ile hizmet vermeye başlamış, 2019 yılı sonu itibariyle bu evlerin sayısı 1.192'e yükselerek 6.164 çocuğa bakım hizmeti verilmiştir. ${ }^{3}$

Ülkemizde çok sayıda çocuğun korunma altına alınmış olması, bu çocuklara yönelik yapılan eğitimleri önemli hale getirmektedir. Kurum bakımı altında olan çocukların alacağı eğitim, sorunlarıyla baş etmeyi öğrenmelerinde, öz güven kazanarak

1 T.C. Aile, Çalışma ve Sosyal Hizmetler Bakanlığı (AÇSHB), "Kurumsal İstatistikler” (Erişim. 15 Eylül 2020).

2 Çocuk Evleri Çalışma Usul ve Esasları Hakkında Yönetmelik (ÇEÇUEHY), Resmî Gazete 27015 (5 Ekim 2008), md. 4.

3 Çocuk Hizmetleri Genel Müdürlüğü (ÇHGM), “Temel Faaliyetlerimiz” (Erişim 5 Temmuz 2020). 
hayata sıkıca tutunmayı başarabilmelerinde ve kendilerini hayatlarının geri kalan kısmını daha bilinçli bir şekilde yaşayabilmelerinde etkili bir unsurdur. Bu çocukların ihtiyacı olan eğitim içerisinde din eğitiminin de büyük payı vardır. Bu çocukların alacağı din eğitimi onların aileden uzak kalma nedeniyle yaşadığı acıların üstesinden gelmelerine ${ }^{4}$, yaşamlarına anlam katarak mutlu ve sosyal bir birey olarak yetişmelerine ve kendilerini bekleyen kötülüklerin farkına vararak zararlı alışkanlıklarla başetmelerine ${ }^{5}$ katkı sağlayacaktır.

Kurum bakımı altında bulunan bazı çocukların sigara, alkol gibi zararlı maddeleri kullanmaları, hırsızlık, fuhuş gibi ahlak dışı davranışlara yönelmeleri, şiddet içerikli davranışlarda bulunmaları, mahremiyet eksikliğinden kaynaklı problemler yaşamaları ve yaşadığı problemlerin üstesinden nasıl geleceklerini bilmeyen çocukların intihar gibi yollara başvurmaları ${ }^{6}$ bu çocukların din eğitimine olan ihtiyacını göstermektedir.

Sevgi Evleri'nde kalan çocukların din eğitimine ihtiyaç duymasının bir diğer nedeni, dinin insan davranışlarına yön veren, insanı zararlı alışkanlıklardan ve kötülüklerden uzak tutan bir unsur olmasıdır. Din eğitimi sayesinde bu çocukların ruhsal ve toplumsal açıdan sağlıklı bir gelişim göstermesi sağlanarak ${ }^{7}$ çocuğun yaşadıklarının acısını başkalarına zarar vererek atlatmaya çalışması önlenebilir. Din eğitimi, çocuğun kendisine ve başkalarına zarar vermesini önleyebilecek bir özelliğe sahiptir. Çünkü çocukların başından geçen olumsuz olayların üstesinden gelebilmesi ve yaşadıklarına karşı sabretmesi din eğitiminin kendilerine sağlayacağı içsel motivasyonla mümkündür. ${ }^{8}$

Korunma altına alınmış çocukların din eğitimine olan ihtiyacı, çok sayıda konuyla ilgili akademik çalışma yapılmasını sağlamıştır. Bu çalışmaların tamamına yer vermek, makalenin hacmini aşması sebebiyle mümkün değildir. Ancak konuyla ilgili yapılan belli başlı çalışmalara değinmekte yarar vardır.

Bu çalışmalardan biri Korunmaya Muhtaç Gençlerin Din Öğretimi İhtiyaçları ${ }^{9}$ isimli eserdir. Eserde yetiştirme yurtlarında kalan gençlerin din öğretimi ihtiyaçlarını belirlemek amacıyla yetiştirme yurtlarında kalan gençlerle, velilerle ve Din Kültürü ve Ahlak Bilgisi Dersi öğretmenleriyle anket yapılmıştır. Araştırma sonucunda gençlerin Allah'ın varlığı, birliği, sıfatları, Hz. Peygamber'in hayatı, kaza, kader, tevekkül, ölüm sonrası hayat gibi konularda bilgi edinmeye ihtiyaç duydukları saptanmıştır.

4 Orhan Demir, Yetiştirme Yurdu Gençliği ve Din Eğitimi (İstanbul: Düşünce Kitabevi, 2004), 182.

5 Leyla Kozan, Korunmaya Muhtaç Çocukların Din Eğitimi (Elazığ: Fırat Üniversitesi, Sosyal Bilimler Enstitüsü, Yüksek Lisans Tezi, 2012), 105-106.

6 Yasemin Davarcı - Zeki Salih Zengin, "Korunma İhtiyacı Olan Çocukların Rehabilitasyonunda Din Eğitiminin Rolü", Journal of Islamic Research 30/2 (2019), 262.

7 Safiye Kesgin, "Kurum Bakımındaki Çocukların Diğer İhtiyaçları Gibi Dini ve Manevi İhtiyaçlarına Duyarlı Bir Yaklaşım: Çocuk Koruma ve Bakım Hizmetleri Ön Lisans Programı”, Uluslararası Sosyal Araştirmalar Dergisi/ Thejournal of International Social Research 13/72 (Ağustos 2020), 971.

8 Davarcı - Zengin, "Korunma İhtiyacı Olan Çocukların Rehabilitasyonunda Din Eğitiminin Rolü”, 272.

9 Saadettin Özdemir, Korunmaya Muhtaç Gençlerin Din Öğretimi İhtiyaçları (Isparta: Tuğra Ofset, 2002). 
Bir diğer çalışma Yetiştirme Yurdu Gençliği ve Din Eğitimi ${ }^{10}$ isimli eserdir. Çalışma yetiştirme yurtlarında kalan gençlerin din eğitimi problemlerini tespit ederek bu problemlere çözüm yolları üretmek amacıyla hazırlanmıştır. Çalışma kapsamında 1218 yaş grubunda olan 665 gence anket uygulanmıştır. Anket sonucunda gençlerin yaklaşı 3/2’ünün ailesinde yeterli bir din eğitimi almadı̆̆ı, yarısının sadece okulda verilen Din Kültürü ve Ahlak Bilgisi Dersi sayesinde dini bilgileri öğrendikleri ve gençlerin \%86,7'sinin din eğitimi ve öğretiminin verilmesini gerekli gördüğü bilgisine ulaşılmıştır. Ayrıca araştırma kapsamında ulaşılan en önemli sonuçlardan biri, küçük yaşlardan itibaren acı olaylarla karşılaşan yetiştirme yurdundaki gençlerin iyi bir din eğitimi sayesinde yaşadıkları sıkıntılarla baş etmeyi öğrenerek hayata sıkıca tutunmayı başarabilmeleridir.

Kurum bakımı altında olan çocukların din eğitimini konu edinen bir diğer çalışma Korunmaya Muhtaç Çocukların Din Eğitimi ${ }^{11}$ isimli çalışmadır. Çalışma; kurum bak1mında olan çocukların yaşadığı problemleri ve bu problemlerin çözümünde din eğitiminin nasıl bir rolü olduğunu ortaya koyan literatür tarama yönteminin kullanılmış olduğu bir yüksek lisans tez çalışmasıdır. Tez, üç bölümden oluşmaktadır. Birinci bölümde, İslam dininde çocuğun önemi; ikinci bölümde, korunmaya muhtaç çocuk kavramı, tarihsel süreçte korunmaya muhtaç çocuklar; üçüncü bölümde ise korunmaya muhtaç çocukların yaşadığı sorunlar ve bu sorunların çözümünde din eğitiminin rolü ele alınmıştır. Araştırmada din eğitiminin, korunmaya muhtaç çocukların hayata tutunmasında, sosyalleşmesinde ve olumsuz davranışlardan uzak kalmasında etkili bir unsur olduğu sonucuna varılmıştır.

Devlet koruması altında olan çocuk ve gençlerin din eğitimini değerlendiren önemli çalışmalardan biri de "Kurum Bakımı Altındaki Çocuklara Yönelik Din Hizmetleri Uygulamalar - Yöntem Ve Öneriler" isimli makaledir. Bu makalede sosyal hizmet kurumlarında Diyanet İşleri Başkanlığı personeli tarafından verilen manevi destek hizmetlerinin niteliği anket çalışmasıyla ortaya konulmaya çalışılmıştır. Araştırmanın temel hedefi sosyal hizmet kurumlarında verilen din hizmetinin niteliği ile ilgili Diyanet İşleri Başkanlığı personelinin görüş ve düşüncelerini ortaya koymaktır. Örneklem grubunu 107 din görevlisin oluşturduğu çalışmada; kurumda verilen din eğitimi ve uygulanma süreci, Diyanet İşleri Başkanlığı'nın kurumda verilen din eğitimi ile ilgili çalışmaları, kurumda çalışan din görevlilerinin pedagojik yaklaşımları anket sorularıyla betimlenmeye çalışılmıştır. Araştırmada elde edilen veriler ışı̆̆ında, kurum bakımı altında olan çocukların din eğitimine ihtiyaç duyduğu, kurumda çalışan din görevlilerinin eğitim düzeyinin yüksek olduğu ancak sosyal hizmet ve manevi danışmanlık konusunda eğitim alması gerektiği, personele yönelik hizmet içi eğitimlerin artırılması gerektiği sonucuna ulaşılmıştır. ${ }^{12}$

10 Orhan Demir, Yetiştirme Yurdu Gençliği ve Din Eğitimi (İstanbul: Düşünce Kitabevi, 2004).

11 Leyla Kozan, Korunmaya Muhtaç Çocukların Din Eğitimi (Elazı̆̆: Fırat Üniversitesi, Sosyal Bilimler Enstitüsü, Yüksek Lisans Tezi, 2012).

12 Hatice Koç Kanca, "Kurum Bakımı Altındaki Çocuklara Yönelik Din Hizmetleri - Uygulamalar - Yöntem ve Öneriler", Diyanet İlmi Dergi 55/1 (Mart 2019), 121-153. 
Konuyla ilgili önemli bir diğer çalışma "Korunma İhtiyacı Olan Çocukların Rehabilitasyonunda Din Eğitiminin Rolü”13 başlıklı makaledir. Bu çalışmada korunma ihtiyacı olan çocuklarla ilgili literatür taraması ayrıntılı bir şekilde yapılmıştır. Araştırma kapsamında din eğitiminin korunma ihtiyacı olan çocukların iyileştirilmesindeki rolü; koruyucu ve önleyici, iyileștirici ve onarıcı, hayatı sürdürmede yardımcı olmak üzere üç grupta ele alınmıştır.

Yukarıda adı geçen çalışmalar korunma ihtiyacı olan çocuk ve gençlerin din eğitimine olan ihtiyacını ortaya koymaktadır. Bu ihtiyaç sebebiyle bu araştırmada da Sivas İl Müftülüğ̈̈'nün kurum bakımı altında olan çocuklara yönelik din eğitimi faaliyetleri ele alınmıștır. Araştırma verileri, yaygın din eğitimi faaliyetlerini yürüten Diyanet İşleri Başkanlığı'na bağlı müftülük personelinin görüşleri doğrultusunda elde edilmiştir. Bu çalışma, kurum bakımı altında olan çocukların din eğitimi ile ilgili sınırlı sayıda yapılan alan çalışmalarına katkı sağlayacak olması, Sivas ilinde Çocuk ve Sevgi Evleri'nde verilen din eğitimi ile ilgili kurumda çalışan din görevlilerinin tamamının görüşünü yansıtması ve bu sayede kurum bakımı altında olan çocuklara verilen din eğitiminin değerlendirilebilmesine katkı sunması açısından önem taşımaktadır.

\section{Araştırmanın Problemi}

Aile yuvasının sıcaklığından, ana baba başta olmak üzere aile bireylerinin ilgi ve gözetiminden uzak kalan çocukların sevgi, ilgi, barınma, korunma ve eğitim gibi ihtiyaçlarının karşılanması oldukça önemlidir. Bu konuda devletin yetkili kurullarına, medya mensuplarına, psikologlara, sosyologlara, eğitimcilere, din görevlilerine ve sivil toplum örgütlerine büyük sorumluluk düşmektedir. Bu sorumluluğun bir gereği olarak bu çalışmada Çocuk/Sevgi Evleri'nde kalan çocukların din eğitimi ihtiyacı göz önünde bulundurulmuş ve çocukların din eğitimi ve öğretimi incelenmiştir.

Araştırmanın problem cümlesini "Sivas Çocuk/Sevgi Evleri”nde yürütülen din eğitimi hizmetlerinin çocuklara katkısı nedir ve bu kurumlarda eğitim hizmeti veren din görevlileri yeterli donanıma sahip midir?" sorusu oluşturmaktadır. Araştırma kapsamında şu sorulara cevap aranmıştır:

1. Çocuk/Sevgi Evleri'nde eğitim veren din görevlileri mesleki yönden yeterli ve tecrübeli midir?

2. Din görevlileri, bu evlerde kalan çocukların sorunları ve ihtiyaçları ile ilgili yeterli derecede bilgi sahibi midir?

3. Din görevlilerine göre çocuklara verilen din eğitiminin çocuklar üzerindeki etkisi nedir?

4. Çocuk/Sevgi Evleri'nde çocuklara uygulanan din eğitimi müfredat programı yeterli midir?

5. Din görevlilerinin çocukların din eğitimi noktasında karşılaştığı zorluklar nelerdir?

13 Yasemin Davarcı - Zeki Salih Zengin, "Korunma İhtiyacı Olan Çocukların Rehabilitasyonunda Din Eğitiminin Rolü”, Journal of Islamic Research 30/2 (2019). 
6. Çocuk/Sevgi Evleri'nde kalan çocuklara daha iyi bir din eğitimi verilebilmesi için din görevlilerinin önerileri nelerdir?

\section{Araştırmanın Yöntemi}

Bu araştırmada din görevlilerine göre Çocuk/Sevgi Evleri'nde kalan çocuklara verilen din eğitimini değerlendirmek amacıyla nitel araştırma modeli kullanılmıştır. Araştırmanın örneklemini Sivas İl Müftülüğü’ne bağlı Çocuk/Sevgi Evleri’nde çalışan 18 din görevlisi oluşturmaktadır. Bu çalışmada, araştırmanın teorik çerçevesini ortaya koymak amacıyla öncelikle nitel araştırma tekniklerinden biri olan "literatür tarama yöntemi” kullanılmıştır. Literatür taramasında, konuyla ilgili olarak din eğitimi alanında yapılmış korunma ihtiyacı olan çocuk ve gençlerle ilgili sınırlı sayıda alan araştırması yapıldığı gözlemlenmiştir. Korunma ihtiyacı olan çocuk ve gençlerin din eğitimi ile ilgili yapılan çalışmalar içerisinde, bu araştırmada elde edilen sonuçları destekleyen bilgilere yeri geldikçe değinilmiştir.

Makalede konuyla ilgili literatür bilgilerinden yararlanmanın yanında, alan araştırması da yapılmış ve nitel araştırma tekniklerinden biri olan "görüşme(mülakat) tekniği” ile araştırmanın verileri toplanmıştır. Görüşme tekniği, iki ve ya daha çok kişi arasında belli bir amaç etrafında yapılan, araştırılan konuda karşılıklı konuşma yoluyla sözel bilgilerin toplandığı bir tekniktir. ${ }^{14}$ Görüşme tekniğinin yüz yüze yapılması, soruşturmanın sözlü oluşu ve soruların cevapsız kalmayışı bu tekniği avantajlı hale getirmektedir. ${ }^{15}$ Görüşme tekniğinin yapılandırılmış, yarı yapılandırılmış ve yapılandırılmamış görüşme olmak üzere üç türü bulunmaktadır. Bu araştırmada görüşme türlerinden yarı-yapılandırılmış görüşme kullanılmıştır. Bu görüşme türünde mülakatı yapan kişi ana hatlarıyla soracağı sorularla ilgili bir yol haritasına sahiptir ancak cevaplayan kişinin ilgi ve bilgisine göre genel çerçeve içerisinde farklı sorular sorarak konunun değişik boyutlarını ortaya çıkarmaya çalışmaktadır. ${ }^{16}$

\section{Verilerin Toplanması}

Sivas Çocuk/Sevgi Evleri'nde yürütülen din eğitimi faaliyetleriyle ilgili bilgi edinme amacıyla Sivas İl Müftülüğğ’ne bağlı çocuk/Sevgi Evleri'nde çalışan din görevlilerine uygulanacak mülakat soruları için öncelikle konuyla ilgili yapılmış diğer çalışmalar incelenmiştir. Araştırmacı, devlet koruması altında bulunan çocuk ve gençlerle daha önceden çalışmış olduğu için orada edindiği tecrübeleri göz önünde bulundurarak ve bu kurumlarda çalışan din görevlilerinin de görüşünü alarak soruları hazırlamıştır. Hazırlanan sorular, din eğitimi alanında çalışmalarını yürüten dört akademisyenin görüşü ve önerileri alınarak düzenlenmiştir.

Din görevlilerine mülakat, Sivas Cumhuriyet Üniversitesi'nden "Etik Kurul Kararı" alındıktan sonra uygulanmıştır. Araştırmada pilot uygulama yapılmadan mülakat

14 Remzi Altunışık vd., Sosyal Bilimlerde Araştırma Yöntemleri, (Sakarya: Sakarya Yayıncıllk, 2007), 82; Çavuş Şahin, "Veri Toplama Teknikleri”, Bilimsel Araștırma Yöntemleri ed. Remzi Y. Kıncal (Ankara: Nobel Yayincllık, 2010), 147.

15 Saim Kaptan, Bilimsel Araştırma ve İstatistik Teknikleri, (Ankara: Tekışık Yayıncılık, 1998), 149.

16 Altunışık vd., Sosyal Bilimlerde Araştırma Yöntemleri, 84. 
26.01.2020 ile 20.03.2020 tarihleri arasında gerçekleştirilmiştir. Araştırmanın örneklem grubunu oluşturan 17 kişi ile görüşme, bireysel olarak ve yüz yüze; 1 kişi ile de pandemi dönemine denk gelmesinden dolayı görüntülü konuşma yoluyla gerçekleştirilmiştir. Mülakat sorularını cevaplayan din görevlilerinin "Katılımcılar İçin Bilgilendirilmiş Gönüllü Olur Formu” imzalamaları istenerek onlardan edinilen bilgilerin bilimsel amaçla kullanılacağı beyan edilmiştir. Katılımcıların mülakat sorularına yönelik cevaplarını rahatlıkla ifade edebilmelerini sağlamak amacıyla kimlik bilgileri araştırmada gizli tutulmuş ve her bir katılımcıya mülakat yapılma tarihine göre K1, K2... şeklinde kod isimler verilmiştir.

\section{Verilerin Analizi}

Araştırmada görüşme (mülakat) yöntemiyle elde edilen veriler betimsel analiz yoluyla yorumlanmıștır. Bu analiz türünde elde edilen veriler daha önceden belirlenen temalara göre özetlenip yorumlanmaktadır. Görüşülen ya da gözlenen kişilerin görüşlerini çarpıcı bir şekilde yansıtmak amacıyla doğrudan alıntıların sıkça yer aldığı betimsel analizde amaç, ham haldeki araştırma verilerinin okuyucunun anlayabileceği ve isterse kullanabileceği bir şekle sokulmasıdır. ${ }^{17}$ Betimsel çalışmalarda en çok kullanılan veri toplama tekniği anket ve mülakattır. ${ }^{18}$

Araştırma kapsamında sonuçların daha objektif bir şekilde yansıtılabilmesi amacıyla, araştırmaya dâhil olan din görevlilerinden alıntılara çokça yer verilmiştir. Katılımcıların verdiği cevaplara göre gruplandırmalar yapılarak elde edilen veriler tablo haline dönüştürülmüş ve daha sistematik biçimde sunulmuştur. Araştırma sonucunda ulaşılan bilgileri destekleyen başka kaynaklara da yeri geldikçe değinilmiştir. Ancak araştırma verilerini destekleyen bilgilere sınırlı sayıda yer verilmiştir.

Araştırmada konunun hassas oluşu göz önünde bulundurularak Çocuk/Sevgi Evleri'nde kalan çocuklarla görüşme yapılamamıştır. Bu nedenle Sivas Çocuk/Sevgi Evleri'nde çocuklara verilen din eğitimi sadece din görevlilerinin ifadelerine göre değerlendirilmiştir.

\section{Bulgular ve Yorum}

3.1. Çocuk Evi/Sevgi Evleri'nde Çalışan Din Görevlileri İle İlgili Demografik Bilgiler

3.1.1. Çocuk Evi/Sevgi Evleri'nde Çalışan Din Görevlilerinin Meslek Grupları

Sivas İl Müftülüğünde çalışan 18 din görevlisinin meslek grupları Tablo 1'de sınıflandırılmıştır.

Tablo 1. Çocuk Evi/Sevgi Evleri'nde Çalışan Din Görevlilerinin Meslek Grupları

Çocuk Evi/Sevgi Evleri'nde Çalışan Din Görevlilerinin Meslek

Kişi Sayısı Oran \% Gruplar1

\begin{tabular}{lll}
\hline Din Hizmetleri Uzmanı (Erkek) & 1 & 5,5 \\
\hline Vaiz (Bayan) & 7 & 38,8 \\
\hline
\end{tabular}

17 Şahin, “Verilerin Analizi”, 188; Altunışık vd., Sosyal Bilimlerde Araştırma Yöntemleri, 268.

18 Kaptan, Bilimsel Araştırma ve İstatistik Yöntemleri, 61. 


\begin{tabular}{lll}
\hline İmam Hatip & 6 & 33,3 \\
\hline Müezzin Kayyım & 3 & 16,6 \\
\hline Kur’an Kursu Öğreticisi (Bayan) & 1 & 5,5 \\
\hline Toplam & $\mathbf{1 8}$ & $\mathbf{1 0 0 , 0}$ \\
\hline
\end{tabular}

Tablo 1'e göre; Sivas'ta Çocuk/Sevgi Evleri'nde çalışan 18 din görevlisinin; \%5,5’i Din Hizmetleri Uzmanı, \%38,8’i Vaiz, \%33,3’ü İmam Hatip, \%16,6’i Müezzin Kayyım, \%5,5’i Kur'an Kursu Öğreticisi'nden oluşmaktadır. Ayrıca bu evlerde çalışan din görevlilerinin \%44,4'ünü bayan, \%55,5'ini ise erkekler oluşturmaktadır. Bu tabloya göre farklı meslek gruplarından ve çoğunluğu erkek olmakla birlikte kadın din görevlileri de bu kurumlarda çalışmaktadır. Bu durum kurumda kalan çocuklar için bir avantajdır. Kurumda hem erkek hem kız çocukların kalıyor olması, onlara kendi cinsiyetlerine göre eğitim verecek bir din görevlisinin bulunması ihtiyacını doğurmaktadır. Kurumda hem erkek hem bayan din görevlilerinin çalışıyor olması, çocukların özellikle ibadet ve ahlak konularında akıllarına takılan her türlü soruyu kendi cinsiyetlerindeki bir görevliye rahatlıkla sorabilmesi açısından bir avantaj olarak değerlendirilebilir.

\subsection{2. Çocuk Evi/Sevgi Evleri'nde Çalışan Din Görevlilerinin Mesleki Tecrübesi}

Çocuk/Sevgi Evleri'nde görevli olan din görevlilerinin mesleki deneyimini belirlemek üzere onlara ilk olarak "Kaç yıldır Diyanet İşleri Başkanlığı'nda çalışıyorsunuz?" sorusu yöneltilmiş ve alınan cevaplar Tablo 2'de gruplandırılmıştır.

Tablo 2. Din Görevlilerinin Diyanet İşleri Başkanlığı'nda Çalışma Süresi

\begin{tabular}{lll}
\hline Din Görevlilerinin Diyanet İşleri Başkanlığı'nda Çalışma Süresi & $\begin{array}{l}\text { Kişi } \\
\text { Sayıs }\end{array}$ & Oran \% \\
\hline $0-10$ yıl & 2 & 11,1 \\
\hline $10-20$ yil & 8 & 44,4 \\
\hline $20-30$ yil & 5 & 27,7 \\
\hline $30-40$ yil & 3 & 16,6 \\
\hline Toplam & 18 & 100,0 \\
\hline
\end{tabular}

Tablo 2'de gösterildiğine göre; Çocuk/Sevgi Evleri'nde çalışan din görevlilerinin \%11,1'i 0-10 yıl arası, \%44,4'ü 10-20 y1l arası, \%27,7'si 20-30 yıl arası, \%16,6's1 30-40 y1l arası bir sürede Diyanet İşleri Başkanlığı'nda çalışmaktadır. Bu tabloya göre Çocuk/Sevgi Evleri'nde çalışan din görevlilerinin mesleki deneyim açısından tecrübeli oldukları görülmektedir.

Çocuk/Sevgi Evleri'nde çalışan din görevlilerinin mesleki deneyimlerini belirlemek için din görevlilerine bir soru daha yöneltilmiştir. "Diyanet İşleri Başkanlığı’ndaki görevinizin kaçınc yılında Sevgi Evleri/Çocuk Evleri'ne gitmeye başladını??" sorusu ile din görevlilerinin bu kurumlarda mesleklerinin kaçıncı yılında çalışmaya başladıkları tespit edilmeye çalışılmış ve bu bağlamda alınan cevaplar Tablo 3'de gruplandırılmıştır.

Tablo 3. Din Görevlilerinin Çocuk Evi/Sevgi Evleri'nde Çalışmaya Başladıkları Mesleki Zaman Dilimi Din Görevlilerinin Çocuk Evi/Sevgi Evleri’nde Çalışmaya Başladık- $\quad$ Kişi Sayısı $\quad$ Oran \% ları Mesleki Zaman Dilimi

\begin{tabular}{lccc}
\hline $0-5$ & yll & 3 & 16,6 \\
\hline $5-10$ & yll & 3 & 16,6 \\
\hline
\end{tabular}




\begin{tabular}{lll}
\hline $10-15$ yll & 6 & 33,3 \\
\hline $20-30$ y1l & 3 & 16,6 \\
\hline $30-40$ yil & 3 & 16,6 \\
\hline Toplam & $\mathbf{1 8}$ & 100,0 \\
\hline
\end{tabular}

Tablo 3'e göre; Çocuk/Sevgi Evleri'nde çalışan din görevlilerinin \%16,6's1 meslek hayatının ilk beş yılında, \%16,6'sı 5 ile 10 yılları arasında, \%33,3'ü 10 ile 15 yılları arasında, \%16,6's1 20 ile 30 yılı arasında ve son olarak \%16,6's1 30 ile 40 yılı arasinda iken Çocuk/Sevgi Evleri'nde çalışmaya başlamıştır. Bu tabloya göre Sivas'ta Çocuk/Sevgi Evleri'nde çalışan din görevlilerinin çalışma yılı itibariyle tecrübeli personel oldukları göze çarpmaktadır.

Koç'un sosyal hizmetler alanında çalışan Diyanet İşleri Başkanlı̆̆g'na bağlı 107 din görevlisiyle gerçekleştirdiği anket çalışmasında da sosyal hizmet kurumlarında çalışan din görevlilerinin görev süresi değerlendirilmiştir. Bu araştırmaya göre örneklem grubunun sosyal hizmet kurumlarında ders verdiği süreye bakıldığında; personelin \%39,3'ünün görev süresinin 3-5 yıl arasında olduğu, \%18,7'sinin 2-3 yıl arasında, \%16,8'inin 5 yıl ve üzeri, \%15,9'unun ise 1-2 yıl arasında olduğu belirlenmiştir. Bu itibarla personelin kurumdaki hizmet süresinin ağırlıklı olarak 3-5 yıl, ikinci olarak 23 yıl arasında olduğu, üçüncü sırayı ise 5 yıl ve üzeri görev yılının aldı̆̆ı görülmektedir. Bu araştırma verileri de din görevlilerinin verdiği hizmeti süreklilik ve birikimlilik esasıyla yürüttüğünü ortaya koymaktadır. ${ }^{19}$ Kurum bakımı altında olan çocuklara eğitim veren din görevlilerinin hem tecrübeli olması hem de bu kurumlarda uzun yıllar çalışması, korunma ihtiyacı olan çocukların din eğitiminden daha fazla istifade etmesine katk1 sunabilecek bir durumdur.

\subsection{3. Çocuk Evi/Sevgi Evleri'nde Çalışan Din Görevlilerinin Eğitim Durumu}

Çocuk/Sevgi Evleri'nde çalışan din görevlilerinin eğitim durumunu tespit etmek amaciyla onlara "Mezuniyet durumunuz nedir?" sorusu yöneltilmiş ve verilen cevaplar aşağıdaki gibi gruplandırılmıştır:

Tablo 4. Çocuk Evi/Sevgi Evleri'nde Çalışan Din Görevlilerinin Eğitim Durumu

\begin{tabular}{lll}
\hline $\begin{array}{l}\text { Çocuk Evi/Sevgi Evleri'nde Çalışan Din Görevlilerinin Eğitim } \\
\text { Durumu }\end{array}$ & Kişi Sayısı & Oran \% \\
\hline İmam Hatip Lisesi & 2 & 11,1 \\
\hline İmam Hatip+İlahiyat Ön Lisans & 7 & 38,8 \\
\hline İlahiyat Ön Lisans+Lisans (ìlahiyat Dışı) & 1 & 5,5 \\
\hline İlahiyat & 2 & 11,1 \\
\hline Lisans+Yüksek Lisans & 6 & 33,3 \\
\hline Toplam & 18 & 100,0
\end{tabular}

Tablo 4'e göre; Çocuk/Sevgi Evleri'nde çalışan din görevlilerinin \%11,1'i İmam Hatip Lisesi, \%38,8'i İmam Hatip Lisesi+Ön Lisans İlahiyat, \%5,5'i İlahiyat Önlisans+Lisans (İlahiyat Fakültesi dışında), \%11,1'i İlahiyat Fakültesi, \%33,3’ü İlahiyat

19 Koç Kanca, “Kurum Bakımı Altındaki Çocuklara Yönelik Din Hizmetleri - Uygulamalar - Yöntem Ve Öneriler”, 126. 
Fakültesi+Yüksek Lisans mezunudur. Tabloya göre bu kurumlarda çalışan din görevlilerinin \%49,9’u dört yıllık lisans mezunu değildir. Dört yıllık ilahiyat mezunu olmayan din görevlilerinin oranı ise \%55'tir.

Koç'un araştırmasına göre ise; Sosyal Hizmet Kurumlarında görev yapan din görevlilerinin \%62,6'sı ön lisans ve lisans mezunu, \%37,4’ü yüksek lisans ve doktora seviyesindedir. ${ }^{20} \mathrm{Bu}$ araştırma sonucuna göre; Sivas ilinde kurum bakımı altında olan çocuklara din eğitimi sunan personelin eğitim seviyesi, Türkiye genelinde sosyal hizmet kurumlarında din eğitimi veren personelin eğitim seviyesinden oldukça düşüktür. Bu durum Sivas ilinde Çocuk/Sevgi Evleri'nde çalışan din görevlilerinin eğitim seviyesi düşük olsa bile genel olarak Sosyal Hizmet Kurumlarında nitelikli personelin çalışmasının önemsendiği görülmektedir. Kurum bakımı altında olan çocukların eğitiminde donanımlı kişilerin yer alması, bu çocukların eğitimi hususunda karşılaşılan güçlüklerin daha kolay aşılabilmesine imkân sağlayabilir.

\section{4. Çocuk Evi/Sevgi Evleri'nde Çalışan Din Görevlilerinin Bu Kurumlarda Çalışma İsteği}

Din görevlilerinin Çocuk/Sevgi Evlerinde gönüllü ya da zorunlu çalıştığını tespit etmek amaciyla onlara "Sevgi Evleri/Çocuk Evleri'nde çalışmanız gönüllü mü yoksa zorunlu mu?” sorusu yöneltilmiştir. Alınan cevaplar Tablo 5'te yer almaktadır:

Tablo 5. Din Görevlilerinin Sevgi Evi/Çocuk Evleri'nde Çalışma İsteği

\begin{tabular}{lll}
\hline Din Görevlilerinin Sevgi Evi/Çocuk Evleri'nde Çalışma İsteği & Kişi Sayısı & Oran \% \\
\hline Zorunlu & 4 & 22,2 \\
\hline Gönüllü & 13 & 72,2 \\
\hline Zorunlu ve Gönüllü & 1 & 5,5 \\
\hline Toplam & 18 & 100,0 \\
\hline
\end{tabular}

Tablo 5'e göre; Çocuk /Sevgi Evleri'nde çalışan din görevlilerinin \%22,2'si işi gereği zorunlu olarak, \%72,2'si gönüllü olarak çalışmaktadır. Çalışan din görevlilerinin \%5,5'i ise zorunlu olarak bu kurumlarda çalışmaya başlamış olmakla birlikte gönüllü bir şekilde korunma ihtiyacı olan çocuklara eğitim için gittiğini ifade etmiştir. Bu tabloya göre Sivas Müftülüğü’ne bağlı Çocuk/Sevgi Evleri’nde çalışan din görevlilerinin \%77,7'si bu kurumlarda zorunlu olarak değil bizzat gönüllü olarak çalışmayı talep etmiştir. Toplumun ayrı bir hassasiyet gerektiren dezavantajlı gruplarında çalışma konusunda din görevlilerinin gönüllü olması, çocuklar için olumlu bir durum olarak yorumlanabilir.

Şanver ve Sarıtunç tarafından din görevlisi veya din eğitimcisi adayı olan İlahiyat Fakültesi öğrencilerinin sosyal hizmet kapsamında dezavantajlı bireylerle çalışma konusundaki hazırbulunuşluğunu ve istekliliğini tespit etmek amacıyla yapılan bir anket çalışmasında; ilahiyat öğrencilerine huzurevi, çocuk yuvası, kadın sığınma evi gibi sosyal hizmet alanlarında vaiz olarak çalışma isteklerine dair soru sorulmuştur. Öğrencilerin \%71,4'ü bu kurumlarda vaiz olarak çalışmayı istediğini, \%28'i ise iste-

20 Koç Kanca, “Kurum Bakımı Altındaki Çocuklara Yönelik Din Hizmetleri - Uygulamalar - Yöntem Ve Öneriler”, 126. 
mediğini belirtmiştir. ${ }^{21} \mathrm{Bu}$ araştırma verilerine göre; toplumun dezavantajl gruplarında çalışma konusunda gönüllü olunması gerektiğini düşünenlerin oranı, Sivas ilinde aynı görüşe sahip din görevlilerinin oranına çok yakındır. Din görevlisi adaylarının öğrencilik yıllarından itibaren bu kurumlarda çalışmaya gönüllü olmaları mesleki temsil açısından olumlu olarak değerlendirilmektedir.

Koç'un yaptığ 1 araştırmaya göre ise; din ve değer eğitiminin Sosyal Hizmet Kurumlarında isteğe bağlı olarak yürütülmesi gerektiği sorusuna; her zaman yanıtını verenlerin oranı $\% 41,1$, genellikle yanıtını verenlerin oranı $\% 19,6$, ara sıra yanıtını verenlerin oranı $\% 15,0$, nadiren yanıtını verenlerin oranı $\% 8,4$, hiç isteğe bağlı olmamalı diyenlerin oranı ise \%15,9'dur. Bu rakamlar sosyal hizmet kurumlarında isteğe bağlı olarak çalışılması gerektiğini düşünen kişilerin toplamda \%60'ı aştığını ancak \%39,3 oranında bir grubun da sosyal hizmet kurumlarında din eğitiminin isteğe bağlı olması konusunda olumsuz görüşe sahip olduğunu göstermektedir. ${ }^{22}$ Dolayısıyla hem bu çalışmada yapılan mülakat hem de her iki anket çalışmasının verilerine göre, katılımcıların büyük çoğunluğu sosyal hizmet kurumlarında din görevlisi olarak çalışmak isteyen kişilerin gönüllü olması gerektiği fikrine sahiptir.

\section{5. Çocuk Evi/Sevgi Evleri'nde Çalışan Din Görevlilerinin Çocuk/Sevgi Evlerinde Kalan Çocuklarla İlgili Bilgi Düzeyi}

Din görevlilerinin sorumlu olduğu evlerde kalan çocukların birtakım özellikleri ile ilgili bilgi sahibi olması, çocuklara nasıl bir yaklaşım sergilemeleri gerektiği hakkında onlara bilgi verecektir. Bu amaçla Sivas'ta Çocuk/Sevgi Evleri'nde çalışan din görevlilerine "Sevgi Evleri/Çocuk Evlerinde çalşmaya başlamadan önce/sonra bu kurumlarda kalan çocuklarla ilgili DiB/Müftülük ya da Aile, Çalş̧ma ve Sosyal Hizmetler Ill Müdürlüğü tarafindan bilgilendirme, eğitim, seminer, kitapçık vs. aldınız mı?" sorusu yöneltilmiştir. Alınan cevaplarla din görevlilerinin bu kurumlarda çalışmaya başlamadan önce hazırbulunuşluk düzeyleri tespit edilmeye çalışılmıştır.

Tablo 6. Din Görevlilerinin Çocuk/Sevgi Evleri'nde Kalan Çocuklarla İlgili Bilgilendirilme Düzeyi

\begin{tabular}{lll}
\hline $\begin{array}{l}\text { Din Görevlilerinin Korunmaya Muhtaç Çocuklarla İlgili Bilgilendirilme } \\
\text { Düzeyi }\end{array}$ & $\begin{array}{l}\text { Kişi } \\
\text { Sayısı }\end{array}$ & $\begin{array}{l}\text { Oran } \\
\%\end{array}$ \\
\hline Çocuk/Sevgi Evleri'nde Çalışmaya Başlamadan Önce Seminer Alanlar & 3 & 16,6 \\
\hline Çocuk/Sevgi Evleri'nde Çalışmaya Başladıktan Sonra Seminer Alanlar & 3 & 16,6 \\
\hline $\begin{array}{l}\text { Çocuk/Sevgi Evleri'nde Çalışmaya Başlamadan Önce ve Sonra Seminer } \\
\text { Alanlar }\end{array}$ & 2 & 11,1 \\
\hline Seminer Almayıp Sadece Kitapçık Alanlar & 10 & 55,5 \\
\hline Toplam & 18 & 100,0 \\
\hline
\end{tabular}

${ }^{21}$ Mehmet Şanver - Berrin Sarıtunç, "Sosyal Hizmet Ve Dezavantajlı Bireylerle Etkileşim Konusunda Din Görevlisi Veya Din Eğitimcisi Adayı Öğrencilerin Görüşleri”, Türkiye Sosyal Araşttrmalar Dergisi 24/20 (Ağustos 2020), 378.

22 Koç Kanca, "Kurum Bakımı Altındaki Çocuklara Yönelik Din Hizmetleri - Uygulamalar - Yöntem Ve Öneriler", 147. 
Tablo 6'ya göre; Sivas Çocuk/Sevgi Evleri'nde çalışan din görevlilerinin \%16,6's1 bu evlerde çalışmaya başlamadan önce; \%16,6'sı çalışmaya başladıktan sonra; \%11,1'i çalışmaya başladıktan önce de sonra da bu çocuklarla ilgili seminer almıştır. \%55,5’i ise Çocuk/Sevgi Evleri'nde çalışmaya başlamadan önce ve sonra seminer ya da başka bir eğitim almamış, onlara sadece bilgilendirici kitapçık dağıtılmıştır.

Şanver ve Sarıtunç'un yaptı̆̆ı araştırmada, ilahiyat öğrencilerinin \%24,2'si sosyal hizmet alanlarında çalışmayla ilgili eğitim, seminer aldıklarını; \%75,8'i ise almadıklarını ifade etmiştir. Aynı zamanda bu öğrencilerin mezun olduktan sonra sosyal hizmet alanında ya da dezavantajlı bireylerle çalışma konusunda kendilerini ne kadar yeterli gördüğü de tespit edilmeye çalışılmıştır. Öğrencilerin \%50,9'u yeterli gördüğünü, \%49,1’i ise yeterli görmediğini ifade etmiştir. ${ }^{23}$ Bu rakamlara göre din görevlileri, öğrencilik yıllarında da dezavantajlı kurumlarda çalışma konusunda yeterli eğitim almamaktadır. Din görevlilerinin bu eğitim eksikliğinin lisans yıllarından itibaren giderilmesi ve bu alanda rehberlik yapacak kişilerin sadece ilahiyat alanında değil sosyal hizmet alanında da yeterli bilgi ve beceriye sahip olması ${ }^{24}$ sağlanmalıdır. Gerekli eğitimi almayan ve bu tür kurumlarda çalışma konusunda kendini yetersiz gören din görevlilerinin çocuklara tam manasıyla faydalı bir eğitim sunmasının zor olduğu bir gerçektir.

Koç'un araştırmasına göre ise; din görevlilerinin \%39,3'ü Diyanet İşleri Başkanlığı'nın Sosyal Hizmet Kurumlarında görev yapan personele yönelik sunmuş olduğu hizmet içi eğitimleri almış, \%61,7'si almamıştır. Bu kurumlarda çalışmaya başladıktan sonra bu kadar yüksek oranda kişinin hizmet içi eğitim almamış olmasının özellikle personel hareketliliğinden kaynaklandığı göz önünde bulundurulmalıdır. Çünkü Aile ve Dinî Rehberlik Daire Başkanlığı, Sosyal Hizmet Kurumlarında görev yapan personele bu eğitimleri periyodik olarak sunmaktadır. ${ }^{25}$ Dolayısıyla sosyal hizmet kurumlarına gerekli eğitimleri almış daimî din görevlilerin atanması bu tür personel hareketliliğinden kaynaklı sorunların önüne geçerek korunma altına alınmış çocukların daha kaliteli bir din eğitimi almasına katkı sağlayabilir.

\section{Din Görevlilerinin Çocuk/Sevgi Evleri'ne Gitme Aralığı}

Din görevlilerinin Çocuk/Sevgi Evleri'nde geçirdikleri süre çocuklara verilen eğitimin verimli ve kalıcı olmasında etkili olan bir unsurdur. Bu sebeple din görevlilerinin Çocuk/Sevgi Evleri'ne gitme aralığını belirlemek amacıyla onlara "Haftada ya da ayda kaç kez bu evlerdeki çocuklara eğitim için gidiyorsunuz?" sorusu yöneltilmiştir. Alınan cevaplar tablo 7'de gruplandırılmıştır.

23 Şanver - Sarıtunç, "Sosyal Hizmet Ve Dezavantajlı Bireylerle Etkileşim Konusunda Din Görevlisi Veya Din Eğitimcisi Adayı Öğrencilerin Görüşleri”, 376.

24 Ali Seyyar - Saadettin Özdemir, “AB Sürecinde Türkiye'de Dini Sosyal Hizmetlerin Önemi TürkiyeAlmanya Örneği”, I. Din Hizmetleri Sempozyumu (3-4 Kasım 2007), ed. Mehmet Bulut (Ankara: DïB Yayınlar1, 2008), 2, 515.

25 Koç Kanca, “Kurum Bakımı Altındaki Çocuklara Yönelik Din Hizmetleri - Uygulamalar - Yöntem Ve Öneriler”, 125-126. 
Tablo 7. Din Görevlilerinin Çocuk/Sevgi Evleri'ne Gitme Aralığ

\begin{tabular}{lll}
\hline Din Görevlilerinin Çocuk/Sevgi Evleri'ne Gitme Aralığı & Kişi Sayısı & Oran \% \\
\hline Haftada Bir Kez & 2 & 11,1 \\
\hline Haftada İki Kez & 14 & 77,7 \\
\hline Haftada Dört Kez & 2 & 11,1 \\
\hline
\end{tabular}

Tablo 7'ye göre; Sivas Çocuk/Sevgi Evleri'nde bulunan din görevlilerinin \%11,1'i haftada bir, \%77,7'si haftada iki, \%11,1'i haftada dört kez eğitim için bu kurumlara gitmektedir. Bu tabloya göre din görevlilerinin Çocuk/Sevgi Evleri'ne gitme aralığ1 çoğunlukla haftada iki kez olmaktadır.

Sivas ilinde din görevlilerinin \%77,7'sinin haftada iki kez kurum bakımı altında olan çocuklara eğitim vermesi azımsanmayacak bir orandır. Çünkü bu kurumda çalışan din görevlilerinin çalışma alanı sadece Çocuk/Sevgi Evleri ile sınırlı değildir. Sık personel değişikliği olmadan, haftada iki kez bu çocuklara verimli bir ders ortamı sağlandığında, çocuklar din eğitiminden daha düzenli olarak faydalanabilir. Ancak bu sürenin artırılmasının gerekliliği ve Diyanet İşleri Başkanlığı tarafından çalışma alanı sadece bu kurumlar olan personellerin istihdam edilmesine olan ihtiyaç açıktır.

\section{7. Çocuk Evi/Sevgi Evleri'nde Çalışan Din Görevlilerinin Yürüttüğü Eğitim Hiz- metleri ile İlgili Bilgiler}

\subsection{Din Görevlileri Tarafindan Çocuk Evi/Sevgi Evleri'nde Uygulanan Program}

Çocuk/Sevgi Evleri'nde verilen din eğitiminin program dâhilinde sürdürülmesi eğitimlerin çocuklar üzerindeki etkisini ve çocukların davranışlarına nasıl yansıdığını öğrenebilmek için çok önemlidir. Bu sebeple Sivas Çocuk/Sevgi Evleri'nde çalışan din görevlilerine "Sevgi Evleri/Çocuk Evleri'nde çalş̧an bir din görevlisi olarak sorumlu olduğunuz çocuk grubuna anlatacağını konularla ilgili DíB ya da Aile, Çalşma ve Sosyal Hizmetler İl Müdürlüğü tarafindan size verilmiş olan bir müfredat var mı?" sorusu yöneltilmiş̦tir.

Sivas Çocuk/Sevgi Evleri'nde çalışan 18 din görevlisinin tamamı Diyanet İşleri Başkanlığ 1 tarafından kendilerine "Etkinliklerle Değerler Eğitimi Kitabı" nın verildiğini ifade etmiştir. İki ciltten oluşan bu kitap, başkanlık tarafından kurum bakımı altında olan çocuklara eğitim hizmeti sunan din görevlileri için kaynak kitap olarak hazırlanmıştır. ${ }^{26}$ Ancak Koç’un araştırmasına göre, Diyanet İşleri Başkanlığı'nın sosyal hizmet kurumlarında yürütülen din ve değer eğitimi uygulamaları konusunda kendilerine belli bir kaynak hazırlandığını ifade edenlerin oranı $\% 25,2$, bu konuda fikir beyan etmeyenlerin oranı \%17,8, başkanlık tarafından herhangi bir kaynak hazırlanmadığını söyleyenlerin oranı ise \%57,0'dir. ${ }^{27}$

Yukarıda ifade edilen rakamlar, Sivas ilinde din görevlilerinin tamamının kendileri için hazırlanmış kaynak kitaptan haberdar olduğunu ancak bu durumun Diyanet

\footnotetext{
${ }^{26}$ Ayrıntılı bilgi için bk. Ercüment Erbay (ed.), Etkinliklerle Değerler Eğitimi I (7-15 yaş) (Ankara: Diyanet İşleri Başkanlı̆̆ı Yayınları, 2018); Erbay, Etkinliklerle Değerler Eğitimi II (7-15 yaş).

27 Koç Kanca, "Kurum Bakımı Altındaki Çocuklara Yönelik Din Hizmetleri - Uygulamalar - Yöntem Ve Öneriler”, 130-136.
} 
İşleri Başkanlığı'na bağlı sosyal hizmet alanında çalışan bütün personel için geçerli olmadığını göstermektedir. Diyanet işleri Başkanlığı’nın sadece sosyal hizmet kurumlarında çalışan din görevlileri için hazırladığı kaynak kitaptan din görevlilerinin haberdar olmayışı, önemli bir eksikliktir. Din görevlilerinin konuyla ilgili bilgi eksikliği yaşamasının sebebi, il müftülüklerinin din görevlilerini yeterince bilgilendirmeyişinden kaynaklı olabilir. Araştırmada elde ettiğimiz verilere göre, Sivas İl Müftülügü tarafından din görevlilerinin konuyla ilgili bilgi edinmeleri sağlanmıștır.

Korunma ihtiyacı olan çocukların kaldığı kurumlarda işlenmesi için hazırlanan Etkinliklerle Değerler Eğitimi Kitabı incelendiğinde, çocuklar için özenle hazırlanmış bir çalışma olduğu görülmektedir. Kitabın birinci cildinde Allah ve Peygamber Sevgisi, Melekleri Tanıyalım, Kur'an-1 Kerim ve Diğer Kutsal Kitaplar, Kader, Ahiret Hayatı, Temizlik, İbadet Bilinci, Helal-Haram, Mahremiyet Bilinci konuları ayrıntılı olarak işlenmiştir. Kitabın ikinci cildinde ise Kul Hakkı, Emanet Bilinci, Sabır, Şükür, Ümit var Olma, İnsan ve Tabiat Sevgisi, Herkesin İyiliğini İstemek, Paylaşma ve Yardımlaşma, İletişim ve İletişim Engelleriyle Baş Etme, Batıl İnançlar, Dua, Vatan ve Bayrak Sevgisi konuları yer almaktadır.

Etkinliklerle Değerler Eğitimi Kitabı'nda çocukların hem kendilerine katkı sağlayacak hem de topluma faydalı bir birey olarak kazandırılmalarını hedefleyen değerlerin öğretiminin yer alması ve etkinliklerde çocuk merkezli yaklaşımın esas alınması dikkat çekmektedir. Kitapta konuların işleniş biçiminin özenle sunulmuş olması, her konunun kazanımının belirtilmesi, soru-cevap, eğitsel oyun, drama, örnek olay inceleme gibi birçok öğretim ilke ve yöntemlerinden faydalanılması, ders etkinliklerinin belirli yaş aralıklarına göre (7-12, 13-15 yaş gibi) hazırlanmış olması bu çalışmayı önemli kılan unsurlardandır. Ayrıca kitapta çocukları üzebilecek anne, baba, aile gibi kavramlara yer verilmemiştir. Bu hassasiyet Çocuk/Sevgi Evleri'nde kalan çocukların duygusal açıdan incitilmemeleri açısından oldukça önemli bir durumdur.

\subsection{Din Görevlilerinin Sevgi Evleri/Çocuk Evleri'nde Verdiği Eğitimin Çocuklar Üzerindeki Etkisi}

Kurum bakımı altında olan çocuklara sunulan din eğitimi hizmetlerinin amacı, ailelerinden ayrı büyüyen ya da onlar tarafından ihmale uğrayan çocukların kendini tanıyan, öz güven sahibi, iletişimi güçlü, üretken, geleceğe umutla bakan bireyler olmasını sağlamaktır. ${ }^{28} \mathrm{Bu}$ sebeple kurum bakımı altında olan çocuklara sunulan din eğitiminin amacına ulaşıp ulaşmadığını belirlemek amacıyla din görevlilerine "Sevgi Evleri/Çocuk Evleri'nde vermiş olduğunuz eğitimin sonuçları gözlemlerinize göre nelerdir?" sorusu yöneltilmiştir.

Din görevlilerinin büyük çoğunluğu kurumda verilen eğitimlerin çocuklar için faydalı olduğunu düşünmektedir. Onlara göre eğitimler çocuklara birçok noktada olumlu etki bırakmaktadır. Benzer sonuç Koç'un araştırmasında da elde edilmiştir. Bu araştırmaya göre; kurumda eğitim faaliyetlerinin ve diğer faaliyetlerin çok faydalı olduğunu

28 Erbay (ed.), Etkinliklerle Değerler Eğitimi I (7-15 yaş), 12. 
düşünenlerin oranı \% 85,1 'dir. Bu oranın çok yüksek olması sevindirici bir durumdur. Ayrıca faydalı olmadığını düşünenlerin oranı, eğitimciden kaynaklı olabilir. ${ }^{29}$

Sivas ilinde din görevlilerinin, Çocuk/Sevgi Evleri'nde verilen eğitimlerin çocuklar üzerindeki etkisine dair görüşleri aşağıda gruplandırılmıştır. Din görevlileri kurum bakımında olan çocuklar için din eğitiminin bir ihtiyaç olduğu, çocukların bilgi ihtiyacı olduğu alanların ve DỉB tarafından giderilmesi gereken eksikliklerin fark edilmesini sağladığı, onların dine ve din görevlisine bakış açısını olumlu etkilediği, bazı zorlukları içermekle birlikte hayata daha sıkı tutunmalarına yardımcı olduğu görüşündedir.

\subsubsection{Kurum Bakımı Altında Olan Çocukların Din Eğitimine İhtiyacı Vardır}

K5, K6, K8, K9, K10, K15, K12 kodlu din görevlileri yapılan eğitimin çocuklara kesinlikle faydalı ve gerekli olduğunu ifade etmiş̦tir. Yapılan eğitimlerin olumlu etkisini din görevlileri şu ifadelerle dile getirmiştir:

K5: "Çocuklar onları seven ve onlara doğru yolu gösteren kişileri çok sevmektedir."

K6: "Biz bu çocuklara manevi olarak rehberlik ediyoruz. Çocuklar bu eğitimlerden mahrum kalısa onları doğru yolda tutmak zorlaşır."

K8: "Bu eğitimler sayesinde çocuklar olgunlaşmakta ve bu olgunluğun onların konuşmalarına ve davranışlarına da yansıdığını görmekteyiz."

K9: "Bu eğitimler sayesinde çocuklar yaptıları eylemleri vicdani noktada daha sorgular hale gelmiştir."

K10: "Kurumda verilen din eğitiminden sonra çocuklar dini konularda daha hassasiyet kazanmış, giydikleri elbisenin, yaptıkları davranışların dine uygun olup olmadığını sormaya bașlamıștr."

K15: "Din eğitimi sayesinde çocuklar bizi aileden biri gibi görüp sevmeye başladılar. Zamanla sevinç ve üzüntülerini bizimle paylaşır oldular."

K12: "Çocuklar bizi seviyorlar ve görmedikleri zaman özlediklerini söylüyorlar."

Yukarıda ifade edildiği üzere din görevlilerinin yaptıkları açılamalar, çocuk/Sevgi Evleri'nde kalan çocukların din görevlilerini sevdiğini, onları kendilerine doğru yolu gösterecek bir rehber olarak gördüklerini ve onlardan öğrendikleri şeyleri yaşamlarında uygulamaya çalıştıklarını ve onları her şeyi paylaşabilecekleri yakın biri olarak gördüklerini göstermektedir.

Yetiştirme yurtlarında kalan ergenler üzerinde yapılan bir çalışmaya göre; "Yaşadıklarınla başa çıkmak için Allah'tan hangi konularda yardım istedin?" sorusuna Bursa' daki katılımcıların \%53,8'i, Şanlıurfa'daki katılımcıların ise \%23,1'i “doğru yolu bulmak için" cevabını vermiştir. ${ }^{30}$ Yetiştirme yurdunda kalan gençlerin doğru yolu bulma isteği konusunda onlara rehberlik edebilecek kişilerin başında kurumda çalışan din görevlileri gelmektedir. Dolayısıyla bu gençlerin ifadeleri kurumda din eğitiminin bir ihtiyaç olduğunun da göstergesidir.

29 Koç Kanca, "Kurum Bakımı Altındaki Çocuklara Yönelik Din Hizmetleri - Uygulamalar - Yöntem Ve Öneriler", 131.

30 Asude Coşkunsever, "Yetiştirme Yurdunda Kalan Ergenlerin Yaşadıkları Sorunlar ve Dini Başa Çıkma: Bursa ve Şanlıurfa Yetiştirme Yurtları Örneği”, Uludağ Üniversitesi İlahiyat Fakültesi Dergisi 25/2 (Ağustos 2016),114. 
Koç'un araştırmasına göre; sosyal hizmet alanında çalışan din görevlilerinden eğitim sürecinde çocukların tutum ve davranışlarında pozitif yönlü değişiklikler gözlemlediğini ifade edenlerin oranı $\% 88,8$, aksi görüşte olanların oranı ise $\% 5,6$ 'dır. ${ }^{31}$ Olumlu yönde görüş beyan edenlerin yüksek oranda olması, kurum bakımı altında olan çocukların din eğitimine ihtiyaç duyduğunu ve bu eğitimlerin onlara olumlu manada tesir ettiğini göstermektedir.

7.2.2. Çocuk/Sevgi Evleri'nde Verilen Din Eğitimi, Çocukların Bilgi Eksikliğinin Olduğu Alanların Fark Edilmesini Sağlamaktadır.

Devlet koruması altındaki çocuklara verilen din eğitimi din görevlileri tarafından çocukların hangi konularda bilgi eksikliği olduğunun fark edilmesini sağlamıştır. K3 ve K5 kodlu din görevlileri bu durumu şu sözleriyle ifade etmiştir.

K3: "Çocuklar anne ve babadan mahrum kalarak büyüdükleri için sevgi, ibadet kavramlarina dair bilgileri bulunmamaktadır."

K5: "Din eğitiminin çocuklara kesinlikle faydası var. Biz onlara manevi anlamda rehberlik ediyoruz. Adap, görgü kuralları noktasında çok eksiklikleri var. Çok güzel dönütler aldığımız çocuklar var."

Din görevlilerinin ifadeleri Çocuk/Sevgi Evleri'nde kalan çocukların ailelerinden ayrı olmaları sebebiyle bazı konularda bilgi eksikliği olduğunu ancak bu eksikliğin verilen eğitimler aracılığıyla giderilebileceğini göstermektedir.

7.2.3. Çocuk/Sevgi Evleri'nde Verilen Din Eğitimi, Diyanet İşleri Başkanlığı Tarafindan Giderilmesi Gereken Bazı Eksikliklerin Fark Edilmesini Sağlamaktadır.

K1 ve K4 kodlu din görevlileri verdikleri din eğitimi sürecinde birtakım zorluklarla karşılaştıklarını ifade etmiştir. Her iki görevlinin de dile getirdiği zorlukların giderilmesi, Diyanet İşleri Başkanlığı'nın sorumluluğundadır. Konuyla ilgili düşüncelerini din görevlileri şu sözlerle dile getirmiştir:

K1: "Bize verilen kaynak kitap, 7-15 yaş aralı̆̆ına hitap ediyor. Onun için pek faydasının olduğunu söyleyemem. Çünkü benim sorumlu olduğum evdeki çocuklar lise çağında."

K4: "Değerler Eğitimi isimli kitap, 7-15 yaş aralığına hitap ediyor. Bu sebeple kitap çok faydalı olmuyor. Benim sorumlu olduğum çocuklar lise çağında ve 7 çocuktan en fazla 2 kişi dini konulara biraz daha ilgili."

Din görevlilerinin ifadeleri, Diyanet İşleri Başkanlığı'nın devlet koruması altındaki farklı yaş grupları için de bir kaynak kitap hazırlaması ihtiyacını doğurmuştur. Çünkü din görevlileri 7-15 yaş aralığı dışında kalan çocuklar için de din eğitimi hizmeti sunmaktadır.

7.2.4. Çocuk/Sevgi Evleri'nde Verilen Din Eğitimi, Çocukların Dine ve Din Görevlilerine Bakışını Olumlu Manada Etkilemekte ve Din Görevlilerini Rol Model Almalarını Sağlamaktadır.

K1, K4, K13, K14 kodlu iki din görevlisi verilen çocukların verdikleri eğitimin bir sonucu olarak camiye, din görevlilerine, dine bakış açılarının olumlu manada farklılaştığını ve kendilerini rol model olarak gördüklerini şu sözlerle ifade etmiştir:

\footnotetext{
${ }^{31}$ Koç Kanca, "Kurum Bakımı Altındaki Çocuklara Yönelik Din Hizmetleri - Uygulamalar - Yöntem Ve
} Öneriler”, 131-132. 
K1: "Ben çocukların ikinci hocasıyım. Çocuklar bizim verdiğimiz dersler sonucunda camiye, imama, dine karşı bakış açılarının olumlu manada değişstiğini söylüyorlar."

K4: "Verdiğimiz eğitimlerden sonra çocukların camiye, imama bakış açıları değişti."

K13: "Çocuklar, ailelerinin tutumlarıyla İslam’ı bağdaştırdıkları ve birtakım yanlış inançlara sahip oldukları için dine karşı olumsuz düşünceler taşıyorlardı. Verilen eğitimlerin sonucunda çocukların İslam Dini 'ne yönelik duyguları olumlu manada değişti ve kendilerini yalnız hissetmeyerek inançlarına uygun davranış geliştirmeye başladılar."

K14: "Koruma altındaki çocuklarla birebir iletişim kurmanın karşılıklı faydalarını görüyoruz. İnanç konularındaki yanlış anlaşılmaları çözüme kavuşturuyoruz. Namaz, tesettür vb. konularda bizleri rol model olarak görüyorlar."

Din görevlilerinin verdiği eğitimler sonucu çocukların dinle ilgili kavramlara karŞ1 beslediği olumsuz düşüncelerin zamanla değişmesi, din görevlilerini örnek alması kurumda verilen din eğitiminin amacına uygun hizmet ettiğini göstermektedir. Koç'un yapmış olduğu araştırmada da çocuklar için iyi bir örnek- rol model olması gerektiğinin her zaman farkında olanların oranı \%83,2, genellikle farkında olduğunu ifade edenlerin oranı \%13,1 olup toplam oran \%96,3'tür. ${ }^{32} \mathrm{Bu}$ oranlar din görevlilerinin çalıştığı kurumlarda çocuklar üzerindeki etkisinin ne kadar büyük ve önemli olduğunu göstermektedir.

\subsection{5. Çocuk/Sevgi Evleri'nde Verilen Din Eğitimi, Çocukların Hayata Tutunması- nı Sağlamaktadır.}

K12 ve K16 kodlu din görevlileri çocukların aldığı din eğitiminin onların geleceğe daha umutla bakmalarını sağladığını şu ifadelerle dile getirmiştir:

K12: "Çocuklar ve gençler zaman içinde bize güvenleri arttıkça kişisel sorunlarını rahatlıkla konuşabilir hale geldiler. Böylece yaşadıkları yüzünden öfke, inanç problemi vs. konuları daha rahat ifade ettiler."

K16: "Çocuklar din eğitimi sayesinde bu hayatın bir imtihan olduğunu ve niçin yaratıldıklarını daha iyi anladılar. Aynı zamanda özgüvenleri arttı. Bu durum hayata daha sevgi dolu ve iyi bakmalarını sağladı."

K12 ve K16 kodlu din görevlisinin gözlemleri, devlet koruması altında olan çocuklara din eğitimi verilmesinin gerekliliğini ortaya koymaktadır. Çünkü din ailesi tarafından ihmal edilen çocuğun yaşamına yeniden bir anlam bulmasını sağlayacak en önemli unsurlar arasında yer almaktadır. Dolayısıyla bu din görevlilerinin gözlemleri bu çocuklara verilen din eğitiminin önemli bir amacı gerçekleștirdiğini göstermektedir.

7.2.6. Çocuk/Sevgi Evleri'nde Din Eğitimi Vermenin Bazı Zorlukları Bulunmaktadır.

K2, K17 kodlu din görevlileri Çocuk/Sevgi Evlerinde kalan çocuklara verilen din eğitimi sonucunda çocuklarla hangi tür konularda zorlandıklarına dair şu açıklamalarda bulunmuştur:

K2: "Beni ilk zamanlar fazla dinlemiyorlardl, şimdi biraz dinliyorlar."

32 Koç Kanca, "Kurum Bakımı Altındaki Çocuklara Yönelik Din Hizmetleri - Uygulamalar - Yöntem Ve Öneriler”, 146-147. 
K17: "Çocuklar dini konuları dinlemeye açıklar. Ancak 12-18 yaş aralı̆̆ındaki çocuklarda uyum sorunu fazla. Çocukların geçmişte yaşadığı boşlukların psikolojik yönlerini düzeltmekte zorlanıyoruz."

Çocukların yaşlarının çok üstünde olumsuz şeyler yaşaması onların anlatılan konuları dinleme isteğine engel olan bir durum olabilir. Aynı zamanda 12-18 yaş grubu çocuklarda uyum sorunu yaşanması çok normaldir. Çünkü bu yaş grubunun ergenlik döneminde olması, aileleri yanında yaşayan çocukların da aile bireyleriyle ya da arkadaşlarıyla her zaman uyum içinde davranışlar sergilemediği bir dönemdir. ${ }^{33}$ Din görevlilerinin bu tür problemleri aşarak sağlıklı bir din eğitimi vermesini sağlayabilmek için çocuk psikologlarından destek almaları sağlanmalıdır. Hatta bazı çocukların kurumda eğitime tabi tutulmadan önce tıbbi olarak tedavi edilmesi gerekebilir. $^{34}$

Genel olarak din görevlilerinin her biri Çocuk/Sevgi Evleri'nde verdikleri din eğitiminin çocuklar için faydalı olduğunu belirtmiştir. Din görevlilerinin ifadeleri din eğitiminin çocukların dini konulardaki yanlış inanç ve düşüncelerinin düzelmesini, yaşamlarının anlam bulmasını, ibadet ve ahlaki konularda dine uygun yaşama bilincinin oluşmasını sağladığını göstermektedir. Bu sebeple din görevlileriyle yapılmış olan bu mülakat, din eğitiminin çocuklar için ne kadar gerekli ve önemli olduğunu bir kez daha vurgulamaktadır.

\subsection{Din Görevlilerinin Sevgi Evleri/Çocuk Evleri'nde Eğitim Faaliyetlerinde Karş1- laştıkları Zorluklar}

Çocuk/Sevgi Evleri, eğitimcilerin okula kıyasla daha fazla güçlüklerle karşılaştıkları ortamlardır. Bu kurumlardaki çocukların zihnen ve ruhen incitilmiş olmaları, onları yeni bir şey öğrenme noktasında isteksiz kılmakta ve bu durum eğitimcilerin yaptıkları işte zorlanmalarına sebep olmaktadır. Sivas Çocuk/Sevgi Evleri'nde çalışan din görevlilerinin bu kurumlarda eğitim faaliyetlerini sürdürürken birçok zorluklarla karşılaştığı düşünülerek onlara "Sevgi Evleri/Çocuk Evleri'nde çalışan bir din görevlisi olarak çocuklarla ilgili karşılaştı̆̆ııı zorluklar nelerdir?” sorusu yöneltilmiştir.

K1, K2, K3, K4, K6, K9, K11, K14 kodlu din görevlileri çocuklara eğitim verirken yaşadıkları zorlukların başında çocukların dikkatini işlenen konulara çekememenin yer aldığını dile getirmiştir. Bu isteksizliği din görevlileri şu sözlerle ifade etmiştir:

K1: "Çocukları bir arada tutmak zor, ders anlatmak gayet zor ama aynı zamanda keyifli ve güzel."

K2: "Çocukların dikkatleri çok dağınık ve sabırsızlar. Öğrettiğimiz şeyleri önemsemiyorlar."

K3: "Anlatılan konuları dinleme ve derse katılım biraz az."

K4: "Çocuklara ders anlatmak zor oluyor."

33 Bk. Serdar Kenan Gül - İsmail Dinçer Güneş, "Ergenlik Dönemi Sorunları ve Şiddet”, Afyon Kocatepe Üniversitesi Sosyal Bilimler Dergisi 11/2 (Haziran 2009), 79-101.

34 Elif Aşık - Fatma Eker, "Yetiştirme Yurdunda Kalan Ergenlerin Sorunları ve Başetmeleri", Kırıkkale Üniversitesi Tip Fakültesi Dergisi 16/2 (Ocak 2016), 29. 
K6: "Çocuklar derslere isteksiz katılıyorlar. Çocukların yaşadıkları ailevi problemler onlara olumsuz etki ediyor."

K7: "Çocuklara her ne kadar devletin ihtimamı olsa da ailelerinden ayrı olmaları onlara olumsuz yansiyor."

K9: "Genç oldukları için ders dinlemeleri ve derse katıllmları biraz zor oluyor."

K11: "Çocuklar başlangıçta bizi dinlemek istemiyor, ön yargıl yaklaşıyorlar. Namaz kılmaya, Kur'an okumaya davet ettiğimizde sinirlenip gidebiliyorlar. Yaşadıkları sıkıntılardan dolayı öfkelerini bize yansitmak isteyebiliyorlar."

K14: "Çocukların hangi sebepten ötürü kurumda kaldığı konusunda bize bilgilendirme yapılmayışı karşıllılı iletişimi zorlaştırıyor. Konsantrasyon ve dinleme problemleri var. Yaşadığı ailevi sıkıntılardan dolayı din eğitimi almak istemeyen öğrenciler var ve bu durum evde gruplaşmaya, alınganlik ve küslüklere sebep oluyor."

Yukarıda ifadeleri bulunan din görevlilerinin açıklamalarına göre çocuklara verilen din eğitimi sürecinde din görevlilerinin genel olarak en çok zorlandığı konular; çocukların dersleri dinlemek istemeyişi, anlatılan konulara ilgi göstermeyişi ve yaşadıkları ailevi sıkıntıların olumsuz etkilerinin derslere de yansımasıdır. Benzer sonuçlara başka araştırmalarda da ulaşılmıştır.

Demir'in yaptığı araștırmaya göre yetiştirme yurdunda kalan çocukların sadece \%3,5'i televizyonda din ve ahlak programlarını izlemektedir. ${ }^{35}$ Aynı şekilde Teker' in yaptığı çalışmada da kurum bakımı altında olan çocukların sadece \%7,5'i serbest zamanlarında manevi sohbet izlemeyi ya da o etkinliğe katılmayı tercih etmektedir. ${ }^{36}$ Aynı araştırmaya göre çocukların televizyonda izlemekten hoşlandıkları program türlerinin dinî, manevî ve ahlaki programların dişındaki programlar olduğu tespit edilmiştir. ${ }^{37} \mathrm{Bu}$ araştırma sonuçları kurum bakımı altında olan çocuk ve gençlerin genel olarak dini konuları dinleme konusunda isteksiz olduklarını göstermektedir.

Çocukların yaşadığı sıkıntıların verilen eğitimleri olumsuz etkilediği açıktır. Kurumda özellikle ergenlik döneminde bulunan çocuklar ailelerinden ayrı olmaları sebebiyle bazı psikolojik problemler yaşayabilir. ${ }^{38} \mathrm{Bu}$ çocukların sosyal davranış sorunlarının temelinde, çocukların yaşamlarında karşılaştıkları örseleyici olgu, olaylar ve engellemelere karşı geliştirdikleri savunma mekanizmaları rol oynamaktadır. ${ }^{39}$ Çocukların sahip olduğu bu olumsuz şartlar çocukların derslere de ilgisiz kalmasına neden olmaktadır.

Sivas Çocuk/Sevgi Evleri'nde çalışan din görevlilerinin kurum bakımında olan çocuklara verilen eğitimlerde çocukların ilgi ve dikkatini derste işlenen konulara

35 Demir, Yetiştirme Yurdu Gençliği ve Din Eğitimi, 139-140.

36 Soner Teker, “Korunmaya ve Bakıma Muhtaç Çocukların Din Eğitimi ve Manevi Bakım Hizmetine Yönelik Görüşleri”, Akademik Araştırmalar Dergisi 66 (2015), 178.

37 Teker, "Korunmaya ve Bakıma Muhtaç Çocukların Din Eğitimi ve Manevi Bakım Hizmetine Yönelik Görüşleri”, 186-187.

38 Coşkunsever, "Yetiştirme Yurdunda Kalan Ergenlerin Yaşadıkları Sorunlar ve Dini Başa Çıkma: Bursa ve Şanlıurfa Yetiştirme Yurtları Örneği”, 103.

39 Coşkunsever, "Yetiştirme Yurdunda Kalan Ergenlerin Yaşadıkları Sorunlar ve Dini Başa Çıkma: Bursa ve Şanlıurfa Yetiştirme Yurtları Örneği”, 106. 
çekemeyişlerinin nedeni, öğreticiden kaynaklanan sorunlar olabilir. Örneğin din görevlisinin kuruma gittiğinde kendisine verilen kaynak kitaptaki sıralamaya göre konu anlatımına başlaması, dersleri her zaman aynı yöntem ya da tekniklerle işlemesi çocukların sıkılmasına ve dinlemek istememelerine sebep olabilir. Koç’un yapmış olduğu araştırmaya göre kurumda yazıll, görsel, işitsel her türlü materyali kullanarak eğitim verdiğini ifade eden din görevlilerinin oranı \%68,3; yazıll, görsel, işitsel her türlü materyali kullanarak eğitim vermediğini belirtenlerin oranı ise $\% 24,3{ }^{\prime}$ tür. $^{40}$ Farklı öğretim yöntem ve tekniklerinden yararlanan din görevlisi sayısının daha da artırılması kurumda yapılan derslere ilgiyi artırabilir.

Din görevlilerinin anlattığı konuların çocukların dikkatini çekemeyişinin sebebi, anlatılan konuların ya da konuların işleniş yönteminin onların yaşlarına uygun olmayışından ya da zihnen ve ruhen dinlemeye hazır olmamalarından kaynaklı olabilir. Örneğin K11 kodlu din görevlisi çocuklarla ilgili karşılaştığı zorlukları şu şekilde ifade etmiştir: "Çocuklar dinlemek istemiyorlar ve ön yargll yaklaşıyorlar. Onları namaz kılmaya, Kuran'i Kerim okumaya davet ettiğimizde sinirlenip gidebiliyorlar. Yaşadıkları sıkıntıları öfkesini bize yansitmak isteyebiliyorlar."

K11 kodlu katılımonnı ifade ettiği problem, nasihat tarzında ders işlemenin kurum bakımı altında olan çocukların ilgisini çekmeyişinden kaynaklı olabilir. Koç'un yapmış olduğu araştırmada çocuklara sürekli nasihat edenlerin oranı \%9,3, genellikle nasihat edenlerin oran $1 \% 26,2$, ara sira nasihat edenlerin oran $1 \% 43,9$, nadiren nasihat edenlerin oranı ise \%19,6 olarak belirlenmiştir. ${ }^{41} \mathrm{Bu}$ rakamlar din görevlileri tarafından nasihat etme yoluna çok başvurulduğunu göstermektedir. Bu durum çocukların verilen derslere ilgisiz kalmalarına neden olabilir.

Din görevlilerinden K3 kodlu katılımcı çocukların anlatılan konulara ilgi göstermesini sağlamak için bir öneri sunmuştur. "Çocukların dini konularda dinleme isteği ve anlatılan konulara katllimı az. Ancak futbol, piknik ya da herhangi bir gezme ortamı istenen konuları anlatmak için değerlendirilirse çocuklarla yapılan faaliyetler daha verimli oluyor." $\mathrm{Bu}$ açıklamalar farklı ortamların çocuklara bir şeyler öğretebilme amacıyla değerlendirilebileceğini göstermektedir. Koç’un yapmış olduğu çalışmada kurumda rutin eğitim faaliyetleri dışında konferans, panel ve gezi gibi etkinlikler gerçekleştirdiğini ifade edenlerin oranı \%65,4; bu hususta fikir belirtmeyenlerin oranı \%9,3; rutin dışı herhangi bir etkinlik gerçekleştirmeyenlerin oranı $\% 25,2$ 'dir. Fikir beyan etmeyen $\% 9,3$ ile bir etkinlik gerçekleştirmeyen \%25,2'lik oranlar oldukça yüksektir. Bu durum resmi kurumlarda izin alınması konusunda problemler yaşanmasından da kaynaklanmaktadır. ${ }^{42}$ Kurumda çalışan din görevlilerinin rutin eğitim faaliyetleri dışında yaptığı çalışmaları artırması ve Aile, Çalışma ve Sosyal Hizmetler Bakanlığı'nın ko-

40 Koç Kanca, "Kurum Bakımı Altındaki Çocuklara Yönelik Din Hizmetleri - Uygulamalar - Yöntem Ve Öneriler", 134.

${ }^{41}$ Koç Kanca, "Kurum Bakımı Altındaki Çocuklara Yönelik Din Hizmetleri - Uygulamalar - Yöntem Ve Öneriler", 142.

42 Koç Kanca, "Kurum Bakımı Altındaki Çocuklara Yönelik Din Hizmetleri - Uygulamalar - Yöntem Ve Öneriler”, 130-131. 
nuyla ilgili izinleri artırması, çocukların verilen eğitimlere daha fazla ilgi göstermesini sağlayabilir.

K5, K17 kodlu din görevlileri çocukların eğitimlerinde karşılaştıkları zorlukları anlatırken farklı bir meseleyi ele almıștır:

K5: "Çocuklar aşır özgürler. Başlarında kimseyi otorite olarak görmüyorlar. Her ihtiyaçları alınyor. Tembellik yapıyorlar ve Nasıl olsa memur olacağız diyorlar. Çocuklara yönelik eğitime ara verdiğimiz dönemde çocuklar çok değişmiş oluyorlar. Çünkü başlarında kalıı bir örnek yok. Bu durum verilen eğitimleri olumsuz etkiliyor."

K17: "Çocuklarda lise mezunu olup 18 yaşııı doldurunca hemen iş sahibi olmanın verdiği bir rahatllk var. Bu durum onların yapılan eğitimlere ilgisiz kalmasina neden olmakta."

K5, K17 kodlu katılımcıların açıklamaları kurum bakımı altında olan çocukların sahip olduğu maddi olanakların, çocukları rehavete sürüklediğini ve bu rehavetin yapılan eğitimleri olumsuz etkilediğini göstermektedir. Korunma ihtiyacı olan çocukların bu tür rehavetlere kapıldığını gösteren başka çalışmalar da bulunmaktadir. ${ }^{43}$

K12, K14 kodlu din görevlileri çocukların kurumda kalma sebeplerini bilmemenin onlarla iletişim kurmada zorlanmalarına sebep olduğunu dile getirmiştir. Bu durumu K14 kodlu din görevlisi "Çocuklarn kuruma gelme hikâyelerini tam olarak bilmiyoruz. Bu sebeple onların gösterdiği aşıı tepkilerinin sebebini anlamamız uzun zaman alıyor." sözleriyle ifade etmiştir.

K12 ve K14 kodlu din görevlileri çocuklarda karşılaştıkları bir başka zorluğun, çocukların çok fazla kişiden (ev annesi, öğretmen, din görevlisi gibi) farklı şeyler öğrenmesinin çocukların bocalamasına sebebiyet vermesi olduğunu ifade etmiştir. K14 kodlu din görevlisi bu sorunu şu ifadelerle dile getirmiştir: "Evlerde bulunan din görevlisi ile bakım personelinin dini konulardaki yönlendirmelerinin birbirine uymaması sorun oluşturmaktadır. Bana sorulan bir dini soru çocuklar tarafindan bakım elemanına da sorulduğunda ikimizin cevabı farkh olabilmektedir."

K16 ve K18 kodlu din görevlileri çocukların başlarına gelen olaylardan dolayı isyankâr olduklarını vurgulamıştır. K16 kodlu din görevlisi çocukların devlete karşı isyankârlı̆̆ını "Çocuklar anne baba sevgisinden mahrum büyüdükleri için sevgiye muhtaçlar. Bu nedenle biraz isyankâr davranmaktadırlar." sözleriyle ifade etmiştir. K18 kodlu din görevlisi ise çocuklardaki isyankârlığı "Çocuklarda aile kavramının ve aile bağlarının zayıf olmasınn etkileri görülmektedir. Bu eksiklik sonucu çocuklar Allah beni neden koruma$d$, beni sevmiyor mu demektedirler" ifadesiyle dile getirmiştir.

Kurum bakımı altında olan çocukların yaşadıklarından dolayı isyankâr olmaları din görevlilerinin vereceği eğitimi daha önemli kılmaktadır. Din görevlilerine kaynak eser olarak verilen Etkinliklerle Değerler Eğitimi kitabında yer alan konulardan biri Kader konusudur. Bu konu kurum bakımı altında olan her yaş grubu çocuk için yaşlarına uygun etkinliklerle titizlikle işlenmelidir. ${ }^{44}$ Kader anlayışının sağlam bir şekilde çocukların zihinlerine yerleşmemesi, onların dinden soğumalarına ve yaşadıkları

43 Özdemir, Korunmaya Muhtaç Gençlerin Din Öğretimi İhtiyaçları, 104.

44 Kozan, Korunmaya Muhtaç Çocukların Din Eğitimi, 96. 
olayların yükünü kaldıramayarak bunalıma düşmelerine neden olabilir. ${ }^{45} \mathrm{Bu}$ tür problemlerin önlenebilmesi için önemli olan bir diğer husus da Allah inancı konusunun sağlıklı bir şekilde işlenmesidir. Bu konu başlığı altında Allah'ın koruyup kollayıc1lı̆̆ , himaye ediciliği, sabredenlerle birlikte oluşu, suçlulara mühlet verişi gibi konulara değinilmesi etkili olabilir. ${ }^{46}$ Bu tür konuların çocuklara nasıl anlatılabileceğine dair din görevlisinin kurumdaki psikologla bilgi alışverişinde bulunması ve konuyla ilgili hazırlanmış bilimsel çalışmalara ${ }^{47}$ bakması çocuklarda doğru bir kader anlayışının yerleşmesine katkı sağlayabilir.

K13 kodlu din görevlisi Çocuk/Sevgi Evleri'nde karşlaştığı zorluklar konusunda yukarıda belirtildiği gibi çocuklarda görülen bir takım davranış problemlerine değinmiş ve bu durumu şu ifadelerle dile getirmiştir. "Çocuklar kimseyi otorite olarak görmedikleri için uç noktalarda bencil davranabilmektedir. Çocukların ergenlik döneminde ve yetişkinlere karşı kırgın, küs olmaları sebebiyle onlarla iletişim zorluğu yaşanmaktadır. Çocuklarla beden mahremiyeti konusunda zorlanabiliyoruz. Ayrıca bakım elemanlarının farklılığı nedeniyle çocukların benlik gelişimleri olumsuz etkilenebilmektedir."

Bu açıklamalar kurum bakımı altında olan çocukların anne babalarının kontrolünde olmadıkları için kendilerini rahat ve istedikleri gibi davranmakta özgür hissettiklerini göstermektedir. Aynı zamanda çocukların ergenlik döneminde bulunması iletişim konusunda yaşanan sıkıntıları da artırmaktadır.

K13 kodlu din görevlisi karşılaştığı zorluklar konusunda bakım elemanlarının farklılığının çocukları olumsuz etkilediğini dile getirmiştir. Din görevlisinin bu ifadesi bakım elemanlarının hangi şartlarla alındığı konusunu gündeme getirmektedir. Bakım elemanının sahip olması gereken nitelikler konuyla ilgili yönetmelikte belirtilmiştir: "Bakıcı anneler/bakım elemanları, kız meslek liselerinin çocuk gelişimi ve eğitimi bölümleri ile fakülte, yüksekokul veya sağlık meslek liselerinin hemşirelik bölümü mezunları veya lise mezunu olup, çocuk bakımı konusunda sertifika sahibi olanlar arasından seçilir."

Yönetmelikte bakım elemanlarında aranan şartlar onların sadece eğitim durumu açısından net bir şekilde ifade edilmiştir. Ancak aranan bu eğitimle ilgili şartlar, bakım elemanlarının çocuklara iyi bir örnek olmaları için yeterli olmayabilir. Örneğin bakım elemanın çocukların yanında konuştuğuna, giyim kuşamına, davranışlarına dikkat etmemesi, çocukların bulunduğu evde ya da gördüğü bir alanda sigara gibi zararlı maddeler kullanması evde bulunan çocuğu olumsuz etkileyecek durumlardır. Bakım elemanlarının çocuklar için uygun bir rol model olmayışı kuruma gelen din görevlilerinin verdiği eğitimi de olumsuz etkileyebilir. ${ }^{49}$

45 Özdemir, Korunmaya Muhtaç Gençlerin Din Öğretimi İhtiyaçları, 101.

46 Davarcı ve Zengin, "Korunma İhtiyacı Olan Çocukların Rehabilitasyonunda Din Eğitiminin Rolü”, 273.

47 bk. Mustafa Öcal, “Kader ve Kaza İnancının Öğretimi”, Uludağ Üniversitesi İlahiyat Fakültesi Dergisi 12/2 (Haziran 2003); Mehmet Ayas, "Kader-Kaza Kavramının Öğretimi ve Kavram Yanılgıları Üzerine Bir İnceleme”, Turkish Academic Research Review 5/3 (Eylül 2020).

48 Çocuk Evleri Çalışma Usul ve Esasları Hakkında Yönetmelik (ÇEÇUEHY), Resmi Gazete 27015 (5 Ekim 2008), md. 13.

49 Kesgin, "Kurum Bakımındaki Çocukların Diğer İhtiyaçları Gibi Dini ve Manevi İhtiyaçlarına Duyarlı Bir Yaklaşım: Çocuk Koruma ve Bakım Hizmetleri Ön Lisans Programı”, 972. 


\subsection{Din Görevlilerinin Sevgi Evleri/çocuk Evlerinde Kalan Çocuklara Daha İyi Bir Din Eğitimi Verilmesine Dair Önerileri}

Devlet koruması altında olan çocuklara eğitim hizmeti sunan din görevlileri çocuklara iyi bir rol model olmanın sorumluluğuyla birlikte kurumda kalan çocuklarla ilgili birçok konuda tecrübe sahibi olmaktadır. Bu tecrübeler ışı̆̆ında din görevlilerinin verilen eğitimlerin nasıl daha verimli olacağına dair yapacakları öneriler, bu çocukların sağlıklı bir şekilde topluma kazandırılmasına katkı sağlayacaktır. Aynı zamanda din görevlilerinin önerileri gelecekte Çocuk/Sevgi Evleri'nde çalısmak isteyen din görevlisi adaylarına da çalışma alanları hakkında ışık tutacaktır. Bu sebeple Sivas'ta Çocuk/Sevgi Evleri'nde çalışan din görevlilerine "Sevgi Evleri/Çocuk Evleri'nde kalan çocuklara daha kaliteli bir din eğitimi verilmesi için önerileriniz nelerdir?" sorusu yöneltilmiştir.

Din görevlilerinin sundukları her bir öneri, hâlihazırda bu kurumlarda çalışan ve gelecekte çalışmak isteyen din görevlisi adaylarına faydalı olacağı düşünülerek gruplaştırılmış ve aşağıdaki başlıklarda maddeler halinde sıralanmıştır.

\subsection{1. Çocuk/Sevgi Evleri'nde Çalışacak Din Görevlisinin Özelliklerine Dair Öneriler}

Din görevlilerinin Çocuk/Sevgi Evleri'nde çalışacak bir din görevlisinde bulunması gereken özelliklere dair sundukları öneriler, bu kurumların içinde yer alan ve kurumda yürütülen eğitim faaliyetlerinin önemli bir kısmını yürüten kişiler olmaları sebebiyle ayrı bir önem arz etmektedir. Aşağıda maddeler halinde sunulan bu önerilerin dikkate alınması, bu kurumlarda din eğitimiyle ilgili yaşanan sorunların tekrarlanmamasına ve verilen eğitimlerin daha kaliteli olmasına katkı sağlayabilir.

1. Çocuk/Sevgi Evleri'nde çalışacak olan din görevlilerinin mesleki açıdan daha deneyimli ve işinde uzman kişiler arasından seçilmesi gerekir. Çünkü çocuklar çok özgür ve kimseyi otorite olarak görmemektedir. Bu sebeple mesleki tecrübesi ve bilgisi az ya da üniversiteden yeni mezun olmuş, yaşı küçük din görevlileri bu kurumda çalışıken zorlanmaktadır.

2. Çocuk/Sevgi Evleri'nde çalı̧̧an din görevlileri mümkünse anne olanlar arasından seçilmelidir. Çünkü din görevlisi aynı zamanda bir anne ise kurumda kalan çocuklara daha fazla ilgi, sevgi ve anlayış gösterebilir.

3. Çocuk/Sevgi Evleri'nde çalışacak olan din görevlilerinin çocuklara yeterince sevgi ve merhamet gösterebilecek bir yapıda olması gerekir.

4. Din eğitimi alan çocuklar yaz tatili gibi din görevlilerinin kuruma gelmediği dönemlerde çok değişmekte ve başlarında kalıcı olarak rol model olacakları bir din görevlisi bulunmadığı için olumsuz davranışlar sergilemektedir. Bu kurumlara daimi bir din görevlisinin atanması din eğitimi faaliyetlerinin daha verimli olmasına büyük katkı sağlayacaktır.

5. Kurumda çalışan din görevlilerinin yaptıkları işi severek ve sorumluluklarının bilincinde olarak yapmaları, kurumdaki görevlerine sadece iş gözüyle bakmamaları gerekir.

6. Çocuk/Sevgi Evleri'nde çalışan din görevlilerinin kuruma düzenli gitmeyişi çocuklarda güven probleminin oluşmasına yol açmaktadır. Bu sebeple din görevlileri- 
nin yaptığı işte samimi olmaları, sabırlı davranmaları çocukların kendilerinden bilgiden ziyade sevgi beklediğini göz önünde bulundurmaları ve kuruma düzenli olarak gitmeleri şarttır.

7. Kurumda çalışan din görevlilerinin seminer vb. eğitimlerle daha donanımlı hale getirilmesi, çocuklara hazırlıksız bir şekilde eğitim verilmesini önleyerek din eğitiminin daha verimli sunulmasını sağlayacaktır.

\subsection{2. Çocuk/Sevgi Evleri'nde Kalan Çocuklara Dair Öneriler}

Çocukların fiziksel, ruhsal, zihinsel, cinsel ve sosyal açıdan sağlıklı bir gelişim göstererek topluma kazandırılması bir ülkenin geleceğini etkileyen bir durumdur. Özellikle toplumun dezavantajlı gruplarında yer alan çocukların iyileştirilerek sosyal hayata dâhil edilmesi geleceğe umutla bakan, yaşama amacı olan nesillerin yetişmesine katkı sağlayacaktır. Bu nedenle Çocuk/Sevgi Evleri'nde çalışan din görevlileri çocuklara faydalı olduğunu düşündükleri din eğitiminden daha fazla verim elde edebilmek için kurumda bulunan çocuklara yönelik iki öneride bulunmuştur:

1. Çocukların iç dünyasında yaşadığı problemlerin tespit edilmesi ve çözüme kavuşturulması gerekir. Aksi takdirde verilen eğitim din eğitimi de dâhil olmak üzere yeterli olmayacaktır. Bu sebeple çocuklara daha iyi bir din eğitimi verilebilmesi için çocukların tek tek ya da grup halinde psikolojik anlamda destek alması gerekir.

2. Sevgi/Çocuk Evleri'nde kalan bazı çocuklar dünyanın bir değerinin olmadığını bu sebeple ahiretin de bir kıymetinin bulunmadığını söylemektedir. Bu düşüncelerine ek olarak, çocuklar devlet tarafından bol maddi imkânlara sahip olduğu için okulun, derslerin önemli olmadığını ifade etmektedir. Çocukların bu bakış açısı din eğitimini de olumsuz etkilemektedir. Bu sebeple din eğitiminin daha küçük yaşlardan itibaren kurum bakımı altında olan çocuklara verilmesi gerekir.

\subsection{3. Çocuk/Sevgi Evleri Kurumuna Dair Öneriler}

Çocuk/Sevgi Evleri gibi korunma ihtiyacı olan kurumlarda kalan çocukların din eğitiminin, onların rehabilitasyonuna katkı sağlaması ve sağlıkl, ahlaklı, iyi bir yetişkin olarak topluma kazandırılması kurumlar arası iş birliğini gerektirmektedir. $\mathrm{Bu}$ konuda özellikle kurum idarecilerinin üzerine düşen görevleri yerine getirmesi, kurumda yapılan eğitim faaliyetlerini her açıdan desteklemesi çocukların verilen eğitimlerden daha fazla verim almasına katkı sağlayabilir. Bu sebeple din görevlileri kurumda verilen din eğitiminin daha etkili olabilmesi için şu önerilerde bulunmuştur:

1. Din eğitiminin daha kaliteli olabilmesi için kurum idaresi tarafından kurumda kalan çocuk, bakım elemanı ve din görevlisi denetlenmelidir. Çocuk din görevlisinden memnun değilse sebepleri araştırılmalı ve gerekli tedbirler alınmalıdır.

2. Kurumda çalışan bakım elemanları çocukların rol modeli olan kişilerdir. Bu elemanların kurum tarafından ahlaklı, manevi ve ahlaki eğitime önem veren kişiler arasından seçilmesi gerekir. Bu şartların aranması, onları birçok konuda örnek alan çocuklara verilen din eğitimini daha kalıcı hale getirecektir.

3. Çocuklara daha kaliteli bir din eğitimi verebilmek için eğitim mekânını bazen değiştirmek etkili olabilir. Çocuk/Sevgi Evleri'nde verilen eğitim, çocuklara sıcak ve 
güvenli bir ortam sağlamakla birlikte din görevlisinin çocuklarla baş başa ders yapabileceği farklı mekânlar sağlanabilir.

4. Çocukların genel anlamda kuruma geliş hikâyelerini bilmemek din görevlilerinin çocuklarla iletişimlerinde ve onlara yönelik eğitimlerinde sorunlar yaşamasına sebep olmaktadır. Bu sebeple din görevlileri çocukların kurumda kalma sebepleri hakkında genel olarak bilgilendirilmelidir.

5. Din görevlilerinin çocuklara verdiği eğitim, bakım elemanları ve kurum idaresi tarafından desteklenmelidir. Din eğitimi kurumdaki çocuklardan sorumlu olan diğer personelle iş birliği içinde yürütülürse daha kaliteli hale gelecektir.

6. Kurumda verilen din eğitimi bütün çocukların evde olduğu bir zaman diliminde ayarlanmalıdır.

7. Çocuk/Sevgi Evleri'ne daimî bir din görevlisi kadrosu açlırsa, bu kadro her zaman aktif ve devamlı olmalı ve görevlinin çocukların din eğitimine yönelik faaliyetleri dışında bir sorumluluğu bulunmamalıdır.

8. Kurumda kalan çocukların kendilerine yönelik eğitim faaliyetlerini önemsemesi ve bu faaliyetlere ilgi göstermesini sağlamak amacıyla yapılan etkinliklere katılım gösteren, dersleri dikkatle dinleyen çocuklar ödüllendirilmelidir.

\subsection{4. Çocuk/Sevgi Evi'nde Kalan Çocuklara Uygulanan Programa Dair Öneriler}

Kurum bakımı altında olan çocuklara uygulanan din eğitimi müfredatının çocukların içinde bulundukları şartlara uygun konuları içermesi, yaşlarına göre düzenlenmiş farklı öğretim yöntem ve teknikleriyle sunulması bu eğitimlerin daha kalıcı hale gelmesini sağlayabilecek bir unsurdur. Din görevlileri müfredatla ilgili iki öneride bulunmuştur:

1. Çocuklara Kur'ân-1 Kerîm'in ve hadislerin daha çok tanitılması ve dini konuların daha fazla anlatılması gerekmektedir.

2. Çocukların gelecek hayatlarında din eğitiminin bir yapı taşı olduğunun bilincinin verilmesi ve ahlaki açıdan iyi yetiştirilmelerinin ön planda tutulması gereklidir.

\section{Sonuç ve Öneriler}

Çocuk/Sevgi Evlerinde verilen din eğitimi, bu kurumda kalan çocukların manevi ihtiyaçlarının karşılanması, hayatla ilgili pek çok konuda yaşanacak muhtemel sorunların çözümü ve toplumla uyumlu, huzurlu ve mutlu bir hayat sürdürmesi açısından önemli bir unsurdur. Özetle din eğitimi, devlet koruması altında olan çocukların ihtiyaç duyduğu ve onların iyi bir yetişkin olarak topluma kazandırılmalarında etkili olabilecek bir role sahiptir.

$\mathrm{Bu}$ araştırmada Sivas Çocuk/Sevgi Evleri'nde çalışan din görevlilerinin Çocuk/Sevgi Evleri'nde kalan çocuklara yönelik din eğitimi faaliyetleri, onlarla gerçekleştirilen yarı yapılandırılmış görüşme tekniği ile incelenmiştir. Araştırma sonucunda Sivas Çocuk/Sevgi Evleri'nde din eğitimi faaliyetleri ile ilgili yapılan tespitler ve öneriler şunlardır:

1. Araştırma kapsamında Sivas Çocuk/Sevgi Evleri'nde çalışan din görevlilerinin büyük çoğunluğunun İlahiyat Fakültesi mezunu olmadığı tespit edilmiştir. Devlet 
koruması altında olan çocukların bakımı ve büyütülmesi özel bir ilgi gerektirdiği gibi eğitimleri de ayrı bir özen gerektirmektedir. Çocuk eğitiminin önemli bir parçası olan din eğitiminin çocuğa en güzel şekilde verilmesi, çocuğun dine bakış açısının küçük yaşlardan itibaren sağlam bir zeminde oturtulması ve yaşadığı sıkıntılarla baş edebilmede dinin manevi gücünden yararlanabilmesi ona bu bilgileri sunacak olan din görevlisinin eğitim durumu ile de yakından ilgilidir. Bu sebeple Çocuk/Sevgi Evlerinde kalan çocuklara din eğitimi veren din görevlilerinde öncelikle İlahiyat Fakültesi mezunu olma şartı aranmalıdır. Bu ihtiyacı yetiştirme yurdunda kalan gençler üzerinde yapılan araştırmalar da ortaya koymaktadır..$^{50}$ Hatta bu şarta ek olarak, din görevlilerinde pedagojik formasyon da aranmalıdır. Bu şartlar görevlilerin hangi konunun hangi yöntemle çocukların yaşlarına uygun bir şekilde anlatılmas1 gerektiği noktasında onlara kolaylık sağlayacak ve din görevlilerinin çocukların eğitimi noktasında kendilerini yetersiz ve çaresiz hissetmesine de engel olacaktır.

2. Araş̧ırma sonucunda Sivas Çocuk/Sevgi Evleri'nde çalışan din görevlilerinin çocuk eğitimi konusunda bilgi ve eğitim eksikliği olduğu tespit edilmiştir. Aile sevgisinden yoksun büyüyen bu çocuklara nasıl davranılması gerektiği ve hangi konuların ne şekilde anlatılacağına dair lisans dönemi de dâhil olmak üzere eğitim almamış olan din görevlilerinin vereceği din eğitimi, birçok probleme yol açabilir. Bu problemlerden en önemlisi, deneyimsiz bir din görevlisinin çocuklara nasıl bir eğitim sunacağı konusundaki bilgisizliğinin, çocukların dinden ve din görevlilerinden soğumasına yol açma ihtimalidir. Bu nedenle bu eğitim eksikliğinin lisans yıllarından itibaren giderilmesi sağlanmalıdır. Diyanet İşleri Başkanlığı'na bağlı hizmet yürütmeyi isteyen ilahiyat öğrencilerinin, çocuk istismarı, çocuk hakları, çocuk eğitimi ve çocuk psikolojisi gibi konularda seçmeli dersleri almasının sağlanması bu çocukların daha kaliteli bir din eğitimi almasına katkı sunabilir. Lisans yıllarında gerekli eğitimi alan din görevlisinin korunma ihtiyacı bulunan çocukların yer aldığı kurumlarda çalışmaya başlamadan önce de sonra da belli aralıklarla hizmet içi eğitim alması sağlanmalıdır. Bu eğitimler Diyanet İşleri Başkanlığı, Aile Çalışma ve Sosyal Hizmetler Bakanlığı, Milli Eğitim Bakanlığı, Sağlık Bakanlığı ve RTÜK’ün iş birliği içerisinde yürütülmelidir.

3. Yapılan mülakat neticesinde din görevlilerinin büyük çoğunluğunun Çocuk/Sevgi Evleri'nde gönüllü olarak çalıştıkları tespit edilmiştir. Toplumun dezavantajlı gruplarında çalışan din görevlilerinin kendi istekleri üzere bu kurumlarda çalı̧̧mayı talep etmeleri sevindirici bir durumdur. Gönüllülük esası verilen eğitimin verimliliğini de etkileyen bir unsurdur. Çünkü bu kurumlarda çalş̧an din görevlilerinin sorumlu olduğu evlere sadece iş alanı olarak bakmaları ve oradaki mesai saatini doldurmak için zaman geçirmeye çalışmaları hem kendilerini hem de eğitim vermeye çalıştıkları çocukları mutsuz edebilir. Bu nedenle müftülük tarafından devlet koruması altında bulunan çocuklara din eğitimi hizmeti verecek olan görevlilerde, bazı eğitim şartlarına ek olarak gönüllülük de aranmalıdır. Ayrıca yeterli sayıda gö-

50 Ayrıca bk. Demir, Yetiştirme Yurdu Gençliği ve Din Eğitimi, 182; Kozan, Korunmaya Muhtaç Çocukların Din Eğitimi, 106. 
nüllü personel bulunmadığı takdirde İl Müftülükleri, bu kurumlarda kalan çocukların din eğitimine olan ihtiyacı, din görevlisinin ailesi tarafından ihmal edilmiş çocukların yeniden topluma kazandırılmasındaki rolü gibi konularda seminer, konferans, panel gibi eğitim etkinlikleri düzenleyebilir. Bu eğitimlerde bir din görevlisinin toplumun dezavantajlı gruplarına yönelik çalışmalar yapmasının manevi bir sorumluluk olduğu vurgulanmalıdır.

4. Araştırmaya göre, din görevlilerinin büyük çoğunluğu haftada iki kez çocuk/Sevgi Evleri'ne eğitim hizmeti için gitmektedir. Din görevlilerinin Çocuk/Sevgi Evleri'nde geçirecekleri bu süreye düzenli olarak riayet etmeleri gerekir. Haftada bir kez bile giden görevlinin zorunlu haller dişında bu kurumlardaki görevini aksatmaması, çocukların din eğitimlerinin aksamaması için gerekli olduğu gibi duygusal açıdan yıpranmamaları için de şarttır. Çünkü bu kurumlarda olan çocuklar ailelerinin yanlarında olmayışından dolayı kendilerine eğitim hizmeti için gelen görevlilere belli bir zaman sonra güven duymakta ve bağlanmakta hatta onları ailelerinden biri olarak görmektedir. Dolayısıyla Çocuk/Sevgi Evleri'nde çalışan her bir din görevlisi zorunlu haller dışında kurumdaki görevini aksatmamalıdır.

5. Yapılan araştırma sonucunda Sivas Çocuk/Sevgi Evleri'nde çalışan din görevlilerinin büyük çoğunluğunun anlattıkları konulara çocukların ilgisini çekerek dinlemelerini sağlama noktasında sorun yaşadığı tespit edilmiştir. Çocukların din görevlilerinin anlattıklarını dinlemek istememeleri çocuklarla konuşularak çözüme kavuşturulabilir. Din görevlisi çocuklara kendisinden neler yapmasını istediklerini sormall; onların merak ettiği, öğrenmek istediği konular varsa öncelikli olarak o konuları işlemelidir. Çocuklar din görevlisini oyun arkadaşı olarak görüyorsa, oyunlar oynanmalı; dertlerini anlatacak biri olarak görüyorsa, çocuklar dinlenmeli; dini konularda aklına takılan şeyleri soracakları biri olarak görüyorsa en güzel şekilde çocuklar bilgilendirilmelidir. Özellikle oyun, din görevlisinin konuları işlerken kazandırmak istediği değerleri çocuklara öğretebilmesi için güzel bir yöntemdir. Dolayısıyla din görevlisi mutlaka kendisine verilen müfredatı uygulama kaygısıyla çocukları sıkmamalı, onların istek ve arzusunu göz önünde bulundurmalıdır.

6. Din görevlileriyle yapılan mülakata göre, Sivas Çocuk/Sevgi Evleri'nde kalan çocuklar din görevlilerini rol model almakta ve çocukların dine bakış açısı din görevlisinin söz ve davranışlarına göre şekillenmektedir. Bu durum söz konusu çocuklara din eğitimi veren din görevlilerinde bulunması gereken özelliklerin önemini vurgulamaktadır. Din görevlileri hiçbir cemaat, tarikat ya da siyasi partinin sempatizanlığını yapmamalı ve cemaatler üstü bir anlayışıyla birleştirici, ayrımcılı̆̆a yer vermeyen bir söylemle çocuklara eğitim vermelidir. Aksi takdirde kurum bakımı altında olan çocukların din görevlisine olan sevgi ve ilgisi suistimal edilmiş olacaktır.

7. Sivas Çocuk/Sevgi Evleri'nde din eğitimi hizmeti sunan din görevlileri verdikleri eğitimin çocuklara faydalı olduğu, onların yaşamlarına anlam kattığı, eğitimler sonucu çocukların dini konularla ilgili yanlış inanç ve düşüncelerinin düzeldiği, çocuklarda ibadet ve ahlaki konularda dine uygun yaşama bilincinin oluştuğu görüşündedir. Din görevlilerinin bu gözlemleri devlet koruması altında olan çocukların 
din eğitimine olan ihtiyacını göstermektedir. Bu ihtiyaçtan dolayı din görevlileri Çocuk/Sevgi Evlerinde kalan çocuklara yönelik eğitimleri sırasında ne kadar zorluk yaşasa da sabırlı olmalı, çalışma şevkini yitirmemeli, bu çocukları mutlu bir birey olarak topluma kazandırabilmek için üzerine düşen sorumluluğu yerine getirmelidir.

8. Sevgi/Çocuk Evleri'nde din eğitimine olan ihtiyaç, çocukların kaldığı kurumlara daimî bir din görevlisi atanmasını gerekli kılmaktadır. Bu sayede çocuklar akıllarına takılan dini konuları, merak ettiği ve öğrenmek istediği şeyleri soracakları bir din görevlisine istedikleri zaman ulaşma imkânına sahip olacaktır.

9. Çocuk/Sevgi Evleri'nde kalan çocuklara yönelik din eğitiminin daha verimli olması çocuklara uygulanan programda yapılacak bazı değişikliklerle mümkün olacaktır. Bu bağlamda devlet koruması altında olan çocuklara eğitim veren din görevlileri için hazırlanmış olan "Etkinliklerle Değerler Eğitimi Kitabı" güzel bir çalışma olmakla birlikte kitapta yer alan etkinlik örnekleri çocukların yaş aralığı dikkate alınarak daha titiz bir şekilde hazırlanmalıdır. Kitaplarda yer alacak olan düzenlemeler, çocukların bu derslerden daha çok zevk almasını ve derslere aktif katılımını sağlayabilir. Kurumda farklı yaş gruplarında yer alan çocuklar için hazırlanmasını önerdiğimiz kaynak kitapta, Allah ve Peygamber Sevgisi, Allah ve Hz. Peygamber'in sevdiği ve sevmediği davranışlar, yabancılarla iletişimin sınırları, beden mahremiyeti, dua ve önemi, arkadaş ilişkilerinde gözetilmesi gereken ilkeler, hayâ eğitimi gibi konulara yer verilmesi çocuğun kendisine yönelik ahlak dışı davranışları fark etmesini ve bu tür davranışları başkalarına uygulamaktan da utanç duymasını sağlayabilir.

10. Çocuk/Sevgi Evleri'nde kalan çocuklara din eğitimi sunan görevlileri tarafından özellikle beden mahremiyeti, giyinme adabı, tuvalet adabı, kitle iletişim araçlarını doğru kullanma adabı gibi konuların oyun, tiyatro vb. yöntemlerle işlenerek çocuklara verilen bilgilerin kalıcı olması sağlanmalı ve böylelikle onların birçok yönden kendilerini bekleyen tehlikelere karşı kurumda bilinçlenmesine katkı sunulmalidır.

11. Devlet koruması altında olan çocukların gelecek yaşamlarında doğru karar verebilmelerini sağlayacak bir bilinç kazanmaları amacına yönelik olarak din görevlileri, İslam dininin çocuklara tanıdığı hakları da işlediği konular arasına dâhil etmelidir. Birçok çocuk, hakları ihlal edilerek görmezden gelindiği için mağdur edilmektedir. Dolayısıyla bu konuların işlenmesi çocukların sahip olduğu hakların bilincinde olmasını ve bu haklar çiğnenmek istendiğinde karşı koymasını sağlayabilir. Hatta bu konu işlenirken anayasanın çocuklara tanıdığı hakların da öğretilmesi çocukların kendi hakları konusunda ayrıntılı bilgi sahibi olmaları hususunda katkı sunacaktır. Örneğin kurumda kalan bir çocuğun, reşit olmadan evlenmenin sakıncalarını, resmi nikâh olmadan dini nikâh kıydırılmasının suç olduğunu bilmesi kendisine art niyetle yaklaşan kişileri fark etmesini sağlayabilir.

12. Çocuk/Sevgi Evleri'nde verilen din eğitimini daha etkili ve verimli hale getirmek için Diyanet İşleri Başkanlığı tarafından akademisyenlerin desteği alınarak farklı öğretim yöntemleri geliştirilmeli ve bu yöntemlerin eğitimi devlet koruması altında bulunan çocuklara din eğitimi sunan din görevlilerine verilmelidir. 
Çocuk/Sevgi Evlerinde verilen din eğitimi faaliyetleri, Sivas ilinde devlet koruması altında bulunan çocuklara din eğitimi veren din görevlileriyle bu çalışmada değerlendirilmiştir. Benzeri çalışmaların farklı illerde bulunan Çocuk/Sevgi Evleri'nde çalışan din görevlileriyle de yapılması, bu kurumlarda verilen din eğitiminin kalitesinin artmasına katkı sağlayacaktır.

\section{Kaynakça}

AÇSHB, Aile, Çalışma ve Sosyal Hizmetler Bakanlığı. "Kurumsal İstatistikler" (15 Eylül 2020). https://www.ailevecalisma.gov.tr/istatistikler\#

Altunışık, Remzi vd.. Sosyal Bilimlerde Araştırma Yöntemleri. Sakarya: Sakarya Yayıncılık, 5. Baskı, 2007. Aşık, Elif - Eker, Fatma. "Yetiştirme Yurdunda Kalan Ergenlerin Sorunları ve Başetmeleri". Kirkkale Üniversitesi Tip Fakültesi Dergisi 16/2 (Ocak 2016), 20-31.

https://doi.org/10.24938/kutfd.124888

Ayas, Mehmet. 'Kader-Kaza' Kavramının Öğretimi ve Kavram Yanılgıları Üzerine Bir İnceleme". Turkish Academic Research Review 5/3 (Eylül 2020), 358-380. https://doi.org/10.30622/tarr.774502

Coşkunsever, Asude. "Yetiştirme Yurdunda Kalan Ergenlerin Yaşadıkları Sorunlar ve Dini Başa Çıkma: Bursa ve Şanlıurfa Yetiştirme Yurtları Örneği". Uludağ Üniversitesi İlahiyat Fakültesi Dergisi 25/2 (Ağustos 2016). 96-124.

ÇEÇUEHY, Çocuk Evleri Çalışma Usul ve Esasları Hakkında Yönetmelik. Resmi Gazete 27015 (5 Ekim 2008). Erişim 5 Ağustos 2020. https://www.resmigazete.gov.tr/eskiler/2008/10/200810051.htm

ÇHGM, Çocuk Hizmetleri Genel Müdürlüğü. “Temel Faaliyetlerimiz”. Erişim 5 Temmuz 2020. https://ailevecalisma.gov.tr/media/37195/chgm-faaliyetler-ve-hedefler.pdf

Davarcı, Yasemin - Zengin, Zeki Salih. "Korunma İhtiyacı Olan Çocukların Rehabilitasyonunda Din Eğitiminin Rolü”. Journal of Islamic Research 30/2 (2019), 255-277.

Demir, Orhan. Yetiştirme Yurdu Gençliği ve Din Eğitimi. İstanbul: Düşünce Kitabevi, 2004.

Erbay, Ercüment (ed.). Etkinliklerle Değerler Eğitimi I (7-15 yaş). Ankara: Diyanet İşleri Başkanlığı Yayınları, 2. Basım, 2018.

Erbay, Ercüment (ed.). Etkinliklerle Değerler Eğitimi II (7-15 yaş). Ankara: Diyanet İşleri Başkanlığı Yayınları, 2. Basım, 2018.

Gül, Serdar Kenan - Güneş, İsmail Dinçer. "Ergenlik Dönemi Sorunları ve Şiddet”. Afyon Kocatepe Üniversitesi Sosyal Bilimler Dergisi 11/1 (Haziran 2009), 79-101.

Kaptan, Saim. Bilimsel Araştırma ve İstatistik Teknikleri. Ankara: Tekışı Yayıncılık, 11. Baskı, 1998.

Kesgin, Safiye. "Kurum Bakımındaki Çocukların Diğer İhtiyaçları Gibi Dini ve Manevi İhtiyaçlarına Duyarlı Bir Yaklaşım: Çocuk Koruma ve Bakım Hizmetleri Ön Lisans Programı". Uluslararası Sosyal Arasțtrmalar Dergisi/The Journal of International Social Research 13/72 (Ağustos 2020), 960-975.

Koç Kanca, Hatice. "Kurum Bakımı Altındaki Çocuklara Yönelik Din Hizmetleri - Uygulamalar Yöntem Ve Öneriler". Diyanet Ilmi Dergi 55/1 (Mart 2019), 121-153.

Kozan, Leyla. Korunmaya Muhtaç Çocukların Din Eğitimi. Elazı̆̆: Fırat Üniversitesi, Sosyal Bilimler Enstitüsü, Yüksek Lisans Tezi, 2012.

Öcal, Mustafa. "Kader ve Kaza İnancının Öğretimi”. Uludağ Üniversitesi İlahiyat Fakültesi Dergisi 12/2 (Haziran 2003), 31-50.

Özdemir, Saadettin. Korunmaya Muhtaç Gençlerin Din Öğretimi İhtiyaçları. Isparta: Tuğra Ofset, 2002. 
Seyyar, Ali - Özdemir, Saadettin. “AB Sürecinde Türkiye'de Dini Sosyal Hizmetlerin Önemi Türkiye-Almanya Örneği”. I. Din Hizmetleri Sempozyumu (3-4 Kasım 2007). ed. Mehmet Bulut. 506-523. Ankara: DİB Yayınları, 2008.

Şahin, Çavuş. "Veri Toplama Teknikleri”. Bilimsel Araştırma Yöntemleri. ed. Remzi Y. Kıncal. Ankara: Nobel Yayıncilik, 2010.

Şanver, Mehmet - Sarıtunç, Berrin. "Sosyal Hizmet ve Dezavantajlı Bireylerle Etkileşim Konusunda Din Görevlisi veya Din Eğitimcisi Adayı Öğrencilerin Görüşleri”. Türkiye Sosyal Araştırmalar Dergisi 24/2 (Ağustos 2020), 373-384.

Teker, Soner. "Korunmaya ve Bakıma Muhtaç Çocukların Din Eğitimi ve Manevi Bakım Hizmetine Yönelik Görüşleri”. Akademik Araştırmalar Dergisi 66 (2015), 167-193. 